Review

\title{
Towards the standardization of stem cell therapy studies for ischemic heart diseases: Bridging the gap between animal models and the clinical setting
}

\author{
Fábio Trindade a,b,* , Adelino Leite-Moreira ${ }^{\mathrm{b}}$, João Ferreira-Martins ${ }^{\mathrm{c}}$, Rita Ferreira ${ }^{\mathrm{d}}$, \\ Inês Falcão-Pires ${ }^{\mathrm{b}}$, Rui Vitorino ${ }^{\mathrm{a}, \mathrm{b}, *}$ \\ a iBiMED, Institute of Biomedicine, Department of Medical Sciences, University of Aveiro, Portugal \\ b Department of Physiology and Cardiothoracic Surgery, Faculty of Medicine, University of Porto, Portugal \\ ${ }^{c}$ Royal Brompton Hospital, Sydney Street, Chelsea, London SW3 6NP, UK \\ d QOPNA, Mass Spectrometry Center, Department of Chemistry, University of Aveiro, Portugal
}

\section{A R T I C L E I N F O}

\section{Article history:}

Received 15 June 2016

Received in revised form 9 November 2016

Accepted 10 November 2016

Available online 14 November 2016

\section{Keywords:}

Stem cell therapy

Regenerative medicine

Animal model

Heart diseases

\begin{abstract}
A B S T R A C T
Today there is an increasing demand for heart transplantations for patients diagnosed with heart failure. Though, shortage of donors as well as the large number of ineligible patients hurdle such treatment option. This, in addition to the considerable number of transplant rejections, has driven the clinical research towards the field of regenerative medicine. Nonetheless, to date, several stem cell therapies tested in animal models fall by the wayside and when they meet the criteria to clinical trials, subjects often exhibit modest improvements. A main issue slowing down the admission of such therapies in the domain of human trials is the lack of protocol standardization between research groups, which hampers comparison between different approaches as well as the lack of thought regarding the clinical translation. In this sense, given the large amount of reports on stem cell therapy studies in animal models reported in the last 3 years, we sought to evaluate their advantages and limitations towards the clinical setting and provide some suggestions for the forthcoming investigations. We expect, with this review, to start a new paradigm on regenerative medicine, by evoking the debate on how to plan novel stem cell therapy studies with animal models in order to achieve more consistent scientific production and accelerate the admission of stem cell therapies in the clinical setting.
\end{abstract}

(c) 2016 Elsevier Ireland Ltd. All rights reserved.

\section{Introduction}

It is well established that heart diseases remain as the leading cause of morbidity and mortality worldwide [1]. Notwithstanding the ability of the myocardium to adapt structural and functionally to a given insult, if not timely attended to, repetitive or persistent insults may eventually overcome the plasticity of the cardiomyocytes (CMs), leading to the cumulative loss of these cells. In such case, an initial compensatory response that preserves normal heart function, may turn into a maladaptive response and advance into (the increasingly prevalent) chronic heart failure (HF) $[2,3]$. Despite the available medications and therapeutic interventions, namely mechanical assist devices, none is capable of restoring cardiac function to the pre-morbid state. Thus, heart transplantation stands as the last treatment option for end-stage chronic HF [4,5]. Unfortunately, shortage of donors, ineligibility of patients with other co-morbidities and the possible transplant rejection account

* Corresponding authors at: iBiMED, Institute of Biomedicine, Department of Biomedical Sciences, University of Aveiro, 3810-193, Aveiro, Portugal.

E-mail addresses: fabiotrindade@ua.pt (F. Trindade), rvitorino@ua.pt (R. Vitorino). for undesirable high mortality rates among patients with this syndrome [6-8]. Hence, it is of utmost interest to develop alternative therapeutics able to restore myocardial function. In this regard, stem cell-based therapies have been a hot topic of research lately. The ultimate goal of stem cell therapy is to replace nonviable myocardium by functional building blocks both at the cellular and tissue levels $[4,9,10]$ and/or to encourage endogenous cardiac repair mechanisms [10,11]. It is our goal to review current investigations on cell therapy for heart diseases as well as to address their limitations and potentials. Given the difficulty in translating the findings of animal model studies to the human cardiovascular clinical paradigm, we propose a flowchart for the design of stem cell therapy studies with animal models, mainly directed to the treatment of ischemic heart diseases, as they represent the main focus of the majority of studies found in literature (Supplementary Table 1) and discussed throughout the following sections.

\section{Stem cells - a brief presentation}

Stem cells display unique properties, making them excellent candidates for the treatment of heart failure: self-renewal, clonogenicity 
and multipotenciality [12]. There are numerous sources of stem cells throughout the body, but each type of cell has their own advantages and limitations, which are abridged in Fig. 1 and discussed in this section. It is not our intention to classify stem cells, but rather designate them in accordance to their origin.

\subsection{Bone-derived stem cells}

\subsubsection{Bone marrow-derived stem cells}

Easily harvested, bone marrow (BM)-derived stem cells are often preferred for stem cell therapy studies $[3,13,14]$. After erythrocyte depletion by centrifugation, one can use bone marrow-derived mononuclear cells (BMMNC), which are a source of both bone marrowderived mesenchymal stem cells (MSC) (BMMSC), endothelial progenitor cells (EPC) and hematopoietic stem cells [15-18]. When compared to other cells, such as cardiac stem cells (CSC) or skeletal muscle stem cells (SkMSC), BM-derived stem cells are more easily collected, cultivated and expanded in vitro, and their use avoid ethical dilemmas, frequently associated with the exploitation of embryonic stem cells (ESC) $[15,19,20]$ (Fig. 1). One of the main advantages of BMMNC and BMMSC is their immunomodulatory properties, that is to say, they are well tolerated by immune cells [10,14,21-23]. Furthermore, these cells can reduce the inflammatory state of the myocardium $[10,22,23]$ and are not teratogenic [24]. It is believed that the main mechanism of BMMNC and BMMSC action is through paracrine activity but direct induction of cardiomyogenesis was also proven possible [25]. These cells are responsible for the release of chemical cues that activate repair mechanisms of endothelial cells and CSCs and promote their migration to the graft site $[13,14,26]$. Among those signals, are angiogenic factors, e.g. vascular endothelial growth factor (VEGF), responsible for stimulating neovascularization, which is of particular importance to replenish the oxygen and nutrients demands of the myocardium after an ischemic lesion as well as to guarantee stem cell survival [16,22,27]. Even though paracrine action is thought to be the main mechanism of their activity, these cells may differentiate into different lineages and can even induce differentiation of other cells to replace non-viable myocardium [28-30].

\subsubsection{Cortical bone-derived stem cells}

Recently, a new source of stem cells has been tested for its therapeutic potential in acute myocardial infarction (AMI). Cortical bone tissue has been used to harvest another family of multipotent stem cells, the cortical bone-derived MSCs (CBMSC), which are suspected to be in a more primitive state, lacking the expression of hematopoietic lineage markers but expressing the pluripotency marker stem cell antigen 1 (Sca-1). When compared to bone marrow, MSC culture from compact bones yields higher numbers of highly homogenous stem cells $\left(2 \times 10^{7}\right.$ versus $\left.3 \times 10^{6}\right)$ in 14 days, thus requiring a lower number of mice to be sacrificed [31]. Although sharing the same mechanisms of action of BM-derived stem cells, CBMSC bring additional advantages (Fig. 1), such as their larger availability and easier isolation, excluding any laborious sorting procedure [32,33]. The promise of CBMSC potential in regenerative medicine was already observed in a mouse model of AMI. In such study, animals treated with CBMSC preserved cardiac function the most, exhibited the best recovery from left ventricle adverse remodeling and such signs were translated into higher survival rates [32].

\subsection{Adipose tissue-derived stem cells}

Stem cells can also be harvested from easily-accessed adipose tissue. Like stem cells obtained from bone tissues, Adipose Tissue-derived Stem Cells (ADMSC) collection is free of ethical concerns and is associated with other pluses (Fig. 1), namely its greater handiness, the minimally invasive nature of collection, the easy and rapid in vitro expansion and the ability to differentiate into distinct lineages, such as cardiac cells [34-41]. Although broadly accepted as immune-privileged, it has been shown that ADMSCs elicit an immune response in vivo [34]. Similarly to BMMNC and BMMSC, its activity is mainly ensued by

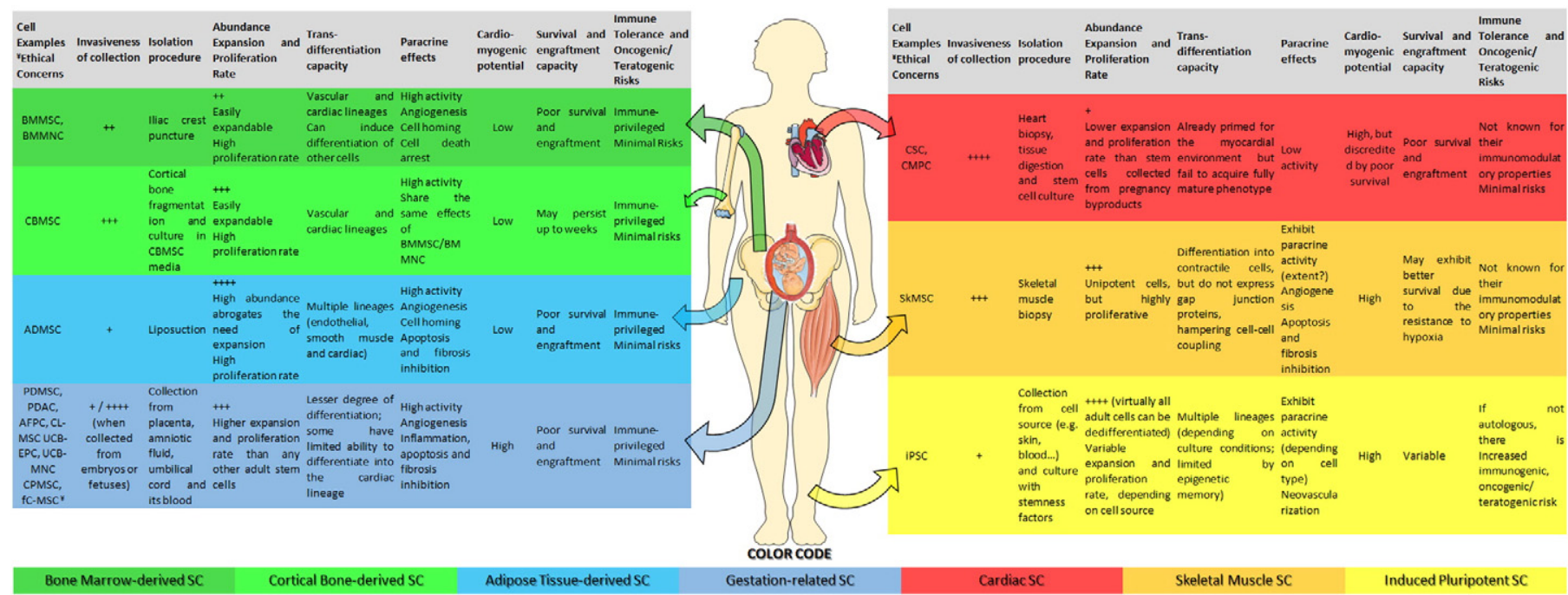

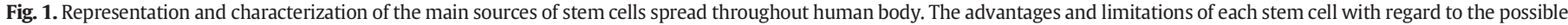

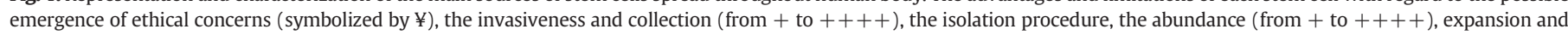

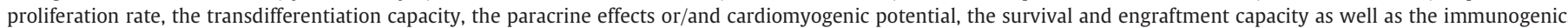

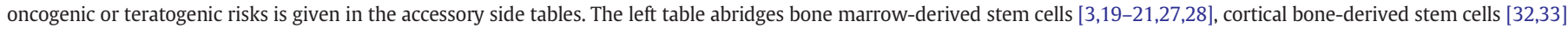

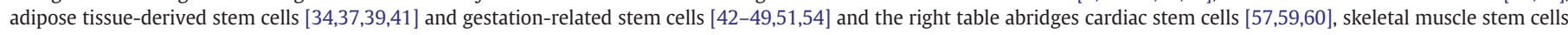

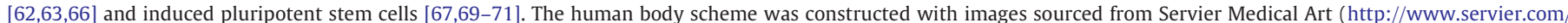

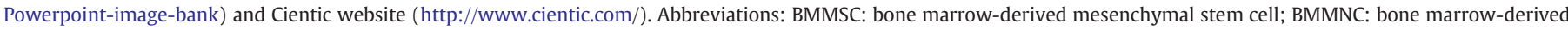

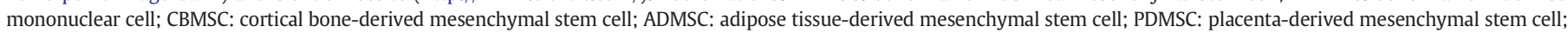

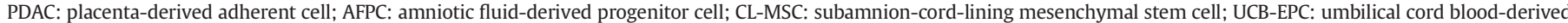

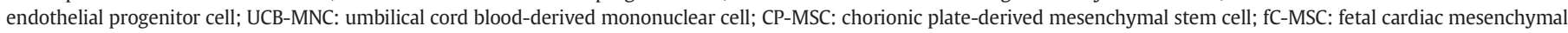
stem cell; CSC: cardiac stem cell; CMPC: cardiomyocyte progenitor cell; SkMSC: skeletal muscle stem cell; iPSC: induced pluripotent stem cell. 
paracrine means and encompasses angiogenesis stimulation, cell death arrest, regulation of fibrosis, but also by direct cardiomyogenesis $[8,37,41]$.

\subsection{Stem cells obtained from pregnancy byproducts and other gestation-re- lated stem cells}

Pregnancy byproducts represent an important source of stem cells which can be obtained from a plethora of sources, such as placenta [42-44], chorionic plate [45], amniotic fluid [46], umbilical cord [47, 48] and its blood [48-51]. These immune-privileged materials offer several advantages (Fig. 1), like their non-invasive, safe and ethically accepted collection, their large availability, as well as their higher expansion and proliferation abilities than any other adult stem cell [42-45]. Furthermore, unlike adult stem cells, pregnancy-associated stem cells are not primed by senescence or disease conditions, thus making them good candidates for regenerative medicine [42]. In addition, cryopreservation of these materials is an already ongoing work that, in the near future, may reveal useful as an autologous reservoir of stem cells [12]. This would be particularly important for elder patients, whose stem cell quality is expected to reduce with age [12]. Similarly to the above stem cell groups, it is thought that these cells act mainly through paracrine activity, stimulating vascularization, cardiomyogenesis, and inhibiting inflammation, fibrosis and apoptosis $[42-45,47,48,51]$. Also related to gestation, MSCs obtained from fetal heart tissue (fC-MSC) and embryonic stem cells (ESC) have been proposed as alternative multipotent cells with the ability to differentiate into CMs, endothelial and smooth muscle cells. However, the use of such cells is obviated by evident ethical dilemmas [52-55].

\subsection{Cardiac stem cells}

Formerly considered as a post-mitotic, terminally differentiated organ, the heart was not conceived as a source of stem cells. Nevertheless, evidence has been building regarding the heart's ability to renew its CM population (albeit at a low rate) [56]. In addition, the isolation of CSC from heart tissue with the capacity to differentiate into CMs and to participate in neovascularization, has set a new paradigm in regenerative medicine $[12,14,57,58]$. These cells have clonogenic and expansion properties and are already primed for the myocardium environment (Fig. 1). Surprisingly, though, they often exhibit poor survival and engraftment [57-59], that is why paracrine activity, mainly pro-angiogenic, has been attributed as their main mechanism of action, rather than the anticipated cardiomyogenic activity [60,61].

\subsection{Skeletal muscle stem cells}

With a relatively easy access through muscle biopsy, SkMSC have also been a choice for cell therapy studies. SkMSC are easily isolated and cultivated and are able to differentiate into contractile cells. In addition, resistance to low oxygen tension conditions have been reported (Fig. 1) [12,62,63]. However, stem cells collected from skeletal muscle are unipotent and, once transplanted, may induce arrhythmias owing to the lack of expression of gap junction proteins, which are crucial for cell-cell electric coupling [62-64]. Similarly to the aforementioned stem cells, SkMSC main activity is through the release of paracrine cues, such as hepatocyte growth factor (HGF), VEGF and stromal cellderived factor 1 (SDF-1), which exert pro-angiogenic, anti-fibrotic and anti-apoptotic activities $[65,66]$.

\subsection{Induced pluripotent stem cells}

Virtually, all adult cells can be subjected to a dedifferentiation program with a set of stemness factors to become induced pluripotent stem cells (iPSC) [67-69]. If not collected from an autologous source, iPSC are related to immunogenic and teratogenic risks (Fig. 1), though these cells are readily available, as their progenitors are somatic cells, bypassing the ethical concerns related to the collection of ESC [67-70]. Again, paracrine activity is believed to be the main mechanism of iPSC action through, for instance, angiogenesis stimulation [71].

\section{Current challenges and guidelines for the design of future stem cell therapy studies}

The lack of a standardized protocol for the design of experiments in cardiac regenerative medicine using animal models has been pointed out as a major concern when researchers seek to compare their findings with those of their peers. This obviously precludes their translation into clinical trials and, thus, it drops greatly their potential as a future therapeutic option [72]. In this sense, we sought to analyze the reports of the last three years regarding stem cell therapy with animal models and address the main issues in their design (Supplementary Table 1). Following the examination of the studies, we propose the first flow-chart for troubleshooting of stem cell therapy study using animal models (Fig. 2), that can be used as a future reference for novel experiments and, hopefully, will help researchers to bring their therapeutic proposals closer to clinical trials and provide inter-laboratory consistency.

\subsection{Validation of the disease model}

Aside from stem cell therapy studies performed in the setting of nonischemic dilated cardiomyopathy [41], dyssynchronous nonischemic narrow QRS cardiomyopathy [73] and complete atrioventricular block [74] which are rather unique with regard to the disease model, it is possible to weave some generalizations in ischemia- or pressure-related pathologies ascribed in Supplementary Table 1, in order to standardize the design of future animal studies. If the cell therapy is to be tested in the treatment of right ventricular (RV) chronic pressure overload, then the pulmonary artery banding is an alternative to test stem cell preventive effects of RV dilation. Given the chronic nature of the pathology, cell administration should be ensued not before 4 weeks post-surgical intervention [51,55]. With regard to the conditions affecting left ventricle (LV), one can develop models of AMI, chronic myocardial infarction (CMI), chronic myocardial ischemia and HF by two main routes. The first is to induce an ischemia/reperfusion (I/R) injury by temporarily occluding left anterior descending coronary artery (LAD, 22.5\% of the studies) or proximal left circumflex artery (PLCA, $2.5 \%$ of the studies) and the second is to permanently ligate them (75\% of the studies). When choosing the I/R injury model, we suggest to occlude the artery for 30 or $90 \mathrm{~min}$, when dealing with murine models or landrace/Yorkshire pigs, respectively, as they are the most frequent times of occlusion reported in the articles depicted in Supplementary Table 1 (for the canine and Göttingen minipig models, however, it is still not possible to give reference times, since for the former only one study report a 95 min-period for artery occlusion and for the latter only two studies report times of occlusion of 120 and $150 \mathrm{~min}$ ). Regardless of the approach, there should be evidence of infarction, such as, myocardial pallor and reduced LV ejection fraction (LVEF), otherwise one should consider to increase the number of animals in experimental groups (it may exist some degree of variability in the resistance to an ischemic insult derived from rodents' coronary anatomic variations) and to widen time frame between surgery intervention and cell therapy (see below), in order to emphasize the symptoms of infarction (Box 1, Fig. 2). In this sense, it seems that permanent ligation of arteries is more reliable than their temporary occlusion, as van der Spoel et al. [75] found that there was a limited decrease of LVEF in a porcine model of CMI by the means of temporary occlusion of the PLCA ( $75 \mathrm{~min}$ ). Also, in a swine model of AMI characterized by the temporary occlusion of the LAD (90 min) it was observed an increased LVEF at the baseline in the vehicle-treated group unlike the cell-treated ones, which hampers inter-group comparisons [76]. Probably, by switching to a permanent ligation model, LVEF decrease at the baseline would be similar in all 
groups, thus allowing the evaluation of the effects of the therapy in a time fashion. Following the banding or occlusion of the arteries, one should define the time for stem cell administration. In this sense, researchers have chosen diverse time points, though, if one seeks to test the efficacy of stem cell therapy in AMI setting it seems that stem cell delivery right after surgical intervention is the most suitable option

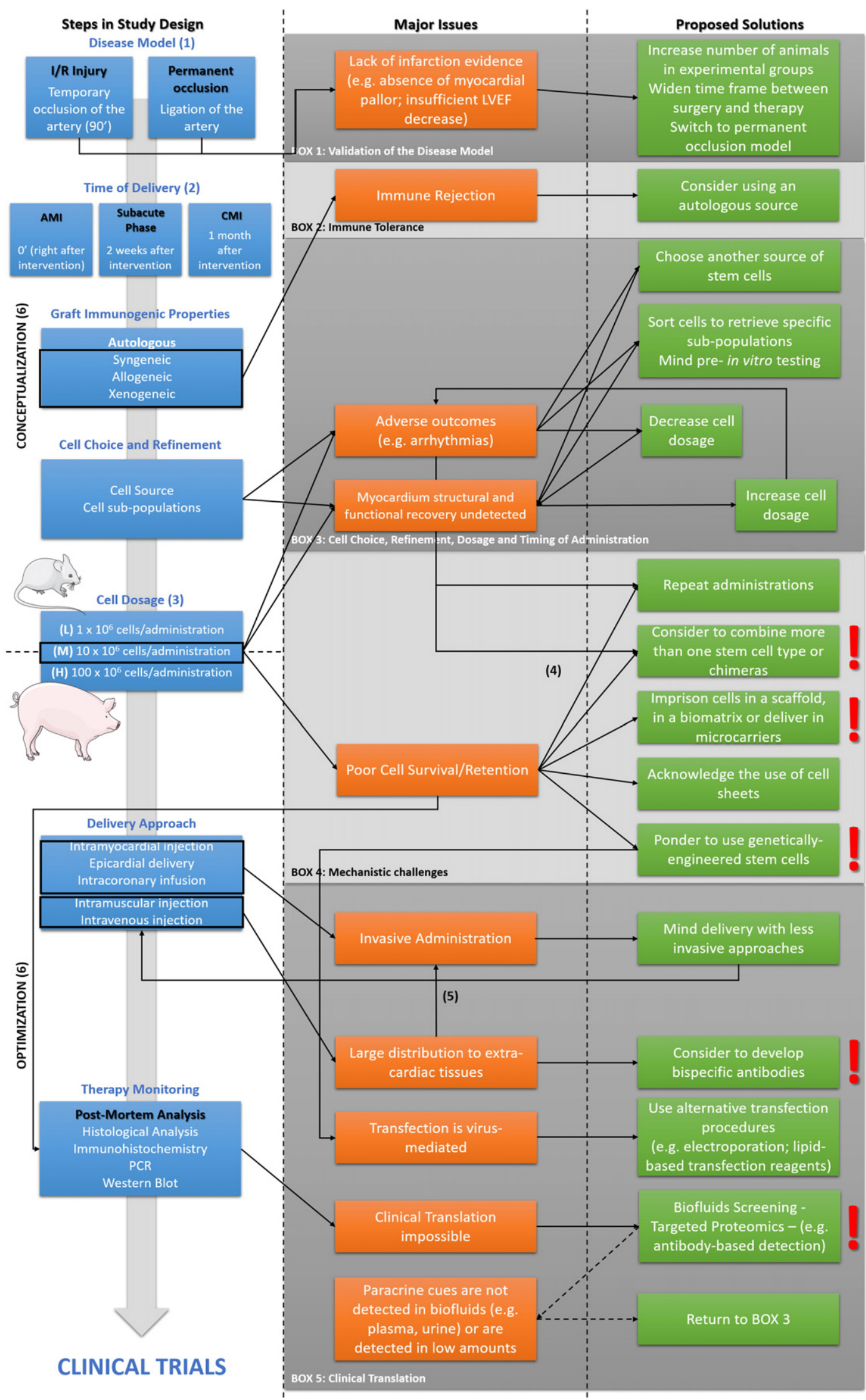


(and the most common in Supplementary Table 1). In turn, if one is looking to investigate the effect of stem cells in subacute phase of infarction, then stem cells should be administered nearly 2 weeks after infarction induction (mean is 17 days after in the studies of Supplementary Table 1). Finally, in CMI, animals should not be treated up until 1 month after infarction induction (mean is 1.3 months after). Consequently, when widening the time gap between surgery and cell transplantation, it is mandatory to respect the boundaries respective to each phase of infarction. That is to say, for the acute phase 2 weeks should be the time limit to observe sufficient myocardial infarction and for the subacute phase, one should not wait longer than one month, otherwise evidences of infarction would show up at the expense of addressing the effects of cell therapy in the chronic phase of infarction.

\subsection{Immune tolerance}

Once the disease model is established, the first challenge that stem cells have to come by is to escape the immune system, that is, to be tolerated by its players. In that matter, xenogeneic transplantation should be the last therapy choice, as it is likely to elicit an immune rejection (Box 2, Fig. 2). Preferably, one should use autologous sources of stem cells. Notwithstanding, this is particularly challenging when dealing with small animal models in the early stages of stem cell therapy experimentation, since collection of autologous cells is limited by the amounts biologically available. Therefore, when autologous cells are not possible, the choice should be made between syngeneic or allogeneic stem cells, which are less immunogenic. In these cases, the administration of immunosuppressive drugs may be necessary, notwithstanding this is not a current practice in clinical trials, which commonly use autologous sources of stem cells [77-97]. Also, animal models of immunodeficiency should be avoided, such as non-obese diabetic/ severe combined immunodeficient mouse model used by Feyen et al. [58] or the athymic nude mice used by Lee and colleagues [98] because they do not represent the normal status of the immune system from patients enrolled in clinical trials.

\subsection{Cell choice, refinement, dosage and timing of administration}

Following stem cell administration, one can face two major issues, i.e. the absence of signs of myocardial structural and functional recovery $[15,34,44,45,62,71,75]$ or the manifestation of adverse outcomes, such as arrhythmia [36]. These can be surpassed mainly by one of three alternatives, namely by electing a different stem cell type, by refining a population of stem cells or by adjusting the cell dosage/number of administrations (Box 3, Fig. 2). Ideally, for each animal model, independent experimental groups should be established to test the safety and efficacy of stem cells collected from different sources in parallel. Furthermore, different strategies should be used to refine cell crude into well-characterized sub-populations. This is a chief issue because when injecting an unselected, heterogeneous stem cell population, one should acknowledge that several pointless and possibly harmful cells are administered concomitantly, which may hinder the activity of scarce stem cells [13].
Cell refinement can be achieved, for instance, by density centrifugation [13], magnetic- (MACS) [26,33] or fluorescence-activated cell sorting (FACS) [99] or by pre-in vitro priming $[8,13,27,33,58,99,100]$. Density centrifugation is often used to isolate mononuclear cells (BMMNC) from BM cell suspension [13,75], while MACS and FACS achieve a higher degree of selectivity by picking up cells according to their surface markers (cluster of differentiation, CD). MACS and FACS can also be used to achieve sub-populations by negative selection, whereby cells are labeled and discarded according to the expression of markers which are not of interest for a particular experiment [33, 99]. Finally, in vitro preconditioning is used to obtain sub-populations endowed to survive in the harsh conditions of the myocardium. One example is by changing/adapting the culture conditions, such as decreasing the chamber oxygen to levels below $5 \%$ to achieve a hypoxic environment $[27,33]$. In addition, it was already reported a different approach to mimic hypoxia by the means of prolyl hydroxylase inhibition [99]. It is expected that cells growing in a low oxygen tension atmosphere are more prepared to endure in the hypoxic myocardium as they are more resistant to apoptosis. That is attributed to the oxygensensitive hypoxia-inducible transcription factor $1 \alpha$ (HIF- $1 \alpha)$, which is stabilized by low levels of oxygen and degraded by prolyl hydroxylases. HIF- $1 \alpha$ dimerizes with HIF- $1 \beta$ to form a heterodimer that translocates to the nucleus and induces a pro-survival and pro-angiogenic gene expression program that protects cells from hypoxia [27,33,99]. Another reported strategy for cell refinement is the enrichment of BMMNC with higher in vitro migratory capacity towards the chemokine SDF-1, which also appears to be correlated with higher proliferative, pro-angiogenic and anti-fibrotic properties [13]. Cells can also be preconditioned by induction of a cardiac program within a cardiomyogenic culture medium [8] or the co-culture of ADMSC with distressed CMs, with the purpose of acclimatizing cells to the environment found in injured myocardia [100].

The number of cells to be administered is another critical variable that comes up while planning a stem cell therapy study. This is particularly important because, similarly to a drug, stem cells are likely to have a therapeutic window, under which there is no effect on the structure and function of the heart and beyond which stem cells can bring undesirable toxic effects. In the last 3 years, experiments with murine models have been using close to $2 \times 10^{6}$ cells (low-dose in Fig. 2 ). When using the canine model, the order of magnitude of the number of cells to be administered increases one unit to $10 \times 10^{6}$ cells $\left(5 \times 10^{6}\right.$ cells on average; medium-dose in Fig. 2). With regard to the swine model, the number of cells rises two units in the order of magnitude, to $100 \times 10^{6}$ cells $\left(72 \times 10^{6}\right.$ cells on average; high-dose in Fig. 2$)$. Ideally, from a hypothetic point of view, stem cell therapy studies enrolling murine, canine or swine species should use 1,10 and $100 \times 10^{6}$ cells, respectively, as preliminary doses. Nevertheless, this is unpractical because the world load of collecting and expanding in vitro stem cells is largely heterogeneous. For instance, CSCs have lower expansion and proliferation rates than ADMSCs or BMMSCs (Fig. 1) and, thus, when dealing with CSCs, researchers administrate only $1 \times 10^{6}$, per animal [14,101]. Also, generally, when working with minipigs the working dose $\left(90 \times 10^{6}\right.$ cells on average) has been usually higher than when working with

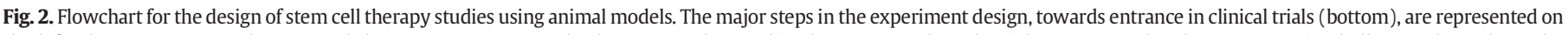

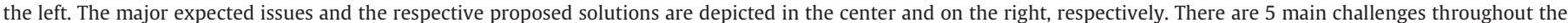

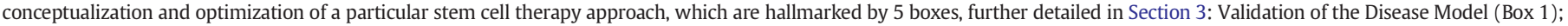

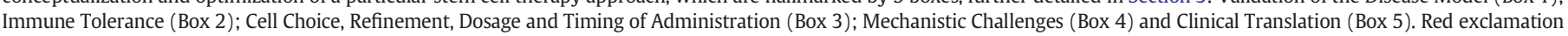

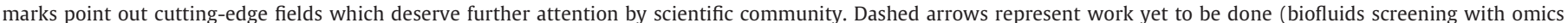

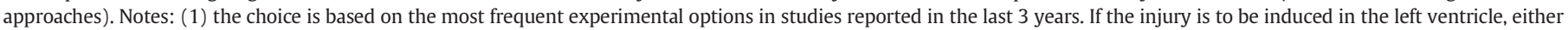

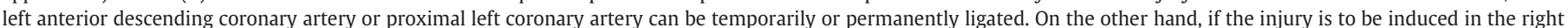

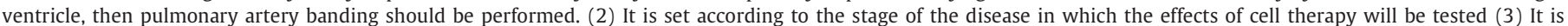

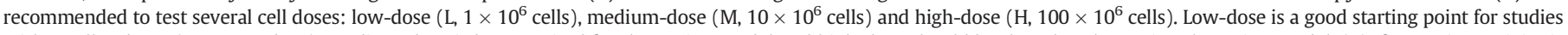

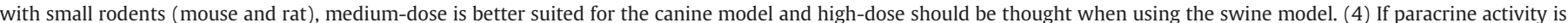

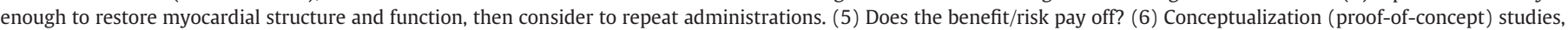

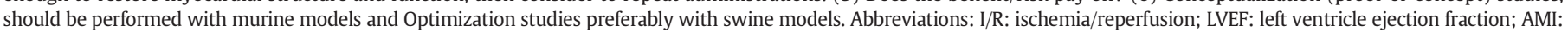
acute myocardial infarction; CMI: chronic myocardial infarction; PCR: Polymerase Chain Reaction. 
larger swine models $\left(30 \times 10^{6}\right.$ cells on average), which adds other variations to the protocols. Still, such average doses could be thought as standard preliminary doses if one wants to discriminate between smaller and larger swine models. Therefore, even though it is not possible to weave generalizations regarding the dose of stem cells to be administered, due to the animal model size, the cell source-dependent availability and culture characteristics in vitro, there is, however, every interest in testing several doses in the same experimental setting, particularly in pre-clinical models. So far, few studies report the effects of different cell dosages and when they do, they are often limited to two-to-three specific doses (Supplementary Table 1). For instance, in a mouse model of AMI it was found that high doses of amniotic fluid-derived progenitor cells ( $4 \times 10^{6}$ cells) brought the best recovery of left ventricular structure and function [46]. Nonetheless, not always the higher dose is the best. For example, Chen et al. [44] showed that a low dose $\left(0.005 \times 10^{6}\right)$ of placenta-derived adherent cells (PDAC) was better than a medium$\left(0.05 \times 10^{6}\right)$ or a high-dose $\left(0.5 \times 10^{6}\right)$ to ameliorate the LV function in a mouse model of HF. In addition, in a swine model of AMI, three doses of CellBeads $^{\mathrm{TM}}$ (alginate-encapsulated MSCs) were analyzed, with the medium dose $\left(20,000\right.$ beads, ca. $1.6 \times 10^{6}$ cells) being more efficient to recuperate LV structure and function [102]. In brief, after a particular stem cell therapy have shown potential in small animal studies we advise researchers to test more than two cell doses with swine models in order to maximize the outcome of the therapy by picking up the most effective dose to be further tested in clinical trials.

The optimization of the stem cell therapy can be also achieved by administration in different time points. For instance, early-high dose administration of CBMSC $\left(2 \times 10^{6}\right.$ cells, right after ligation of the LAD) to a rat model of AMI showed the best performance in improving LV structure and function, when compared to early-low $\left(1 \times 10^{6}\right.$ cells, right after ligation of the LAD), late-low $\left(1 \times 10^{6}\right.$ cells, one week after ligation of the LAD) or late-high $\left(2 \times 10^{6}\right.$ cells, one week after ligation of the LAD) dose administrations [33]. The optimization of the delivery time points is particularly significant if the research focus is heart regeneration in the acute and subacute phases of myocardial infarction. For instance, YiHuan et al. [103] found that injecting BMMSC 2 and 4 weeks after infarction induction resulted in better structural and functional recovery than when injecting $3 \mathrm{~h}$, one or 3 days after infarction induction, probably because in the healed phase of AMI, hypoxia and inflammation are less intense and scar tissue is not completely developed.

\subsection{Mechanistic challenges}

One of the major challenges in stem cell therapy is to guarantee cell retention and survival in the ischemic myocardium [12], once the recovery of myocardial structure and function hinges on their quality and quantity. After being administered, cells can be nearly gone as soon as 1 to 3 days after transplantation $[44,45]$. However, some authors reported signs of stem cell survival up to 1 week [8,16,60,100,104], 1 month $[14,18,23,27,30,37,46,52,67,105]$ and, most strikingly, up to 1 year [26]. When retained cells are quantified, we find that less than $3 \%$ of the stem cells survive more than 4 weeks $[59,70]$ and that percentage drops to levels below $1 \%$ when the assessment is made 16 weeks after transplantation [106]. The exception is reported by Zhang et al. [67] who found that $32 \%$ of the implanted iPSC-CMs could survive for 4 weeks in a mice model of AMI. Several factors account for this misfortunate reality, firstly those related to the administration and implantation of stem cells, like cell leakage, venous drainage and distribution to outer tissues, rejection by immune system, lack of intercellular coupling via gap junctions as well as mechanical extruding due to heart beats and, secondly, those associated to the intrinsic conditions of the myocardium, such as ischemia (with consequent nutrient deprivation and hypoxia), I/R injury, the inflammatory, oxidative and pro-apoptotic environment in addition to anoikis, i.e. programmed cell death by the loss of cell-matrix communication [12,16,18-21,23, 33-36,39-41,49,50,53,59,107-110].
In order to surpass the mechanistic challenges of stem cell implantation, several strategies have been proposed, as debated below. In future studies, we recommend to test as many approaches as possible. In this manner, for each cell at scope, we can choose from a wide range of therapy options, the strategy likely to succeed further in pre-clinical or clinical trials. There is no particular order to follow, although one should acknowledge that genetic engineering does not readily meet consensus in scientific community towards clinical application. Therefore, we recommend to explore all of the other available options before considering to manipulate stem cell genome.

\subsubsection{Repeated administrations}

It is not common to repeat administration of stem cells in animal models. As one can see in Supplementary Table 1, only one group tested the effect of repetitive stem cell administration in the last three years [75]. Using a swine model of CMI, van der Spoel and colleagues tested the effect of 4-week-intervaled administrations of BM-derived stem cells. However, they found that second injection of stem cells did not bring additional advantage [75]. Though, one should not be discouraged to verify the effect of repetitive doses in stem cell therapy, given that it is generally accepted that paracrine activity is the main action of stem cells and, thus, like a drug, repeated inputs of the medicine is likely to improve the recovery of the ill myocardium.

\subsubsection{Combination of different stem cells}

The aim behind combined administration of stem cells is to magnify the therapeutic potential by synergistic activity of different cell types. The most commonly used strategy is to associate CSC, known for its cardiomyogenic potential, with other stem cells known for its paracrine activity or with cells with specific roles $[14,57,101,106,111]$. For instance, in a swine model of AMI, it was found that combined administration of c-kit ${ }^{+}$CSC and BMMSC increased cell engraftment by 7-fold in comparison to the same stem cells alone. Furthermore, with the exception of cardiac output and tau, CSC + BMMSC therapy ameliorated a myriad of structural and functional parameters, over single cell therapies [14]. The same combination was proven to be superior over BMMSC alone in a swine model of HF, as demonstrated by several contractile tests [101]. Latham et al. [106] also demonstrated that combining CSC and circulatory angiogenic cells (CAC, early outgrowth EPC) improved LVEF up to 4 months, while CSC and CAC alone did not improve LVEF over 3 months, in a mouse model of AMI. This can be explained by the complementary paracrine signatures of CSC and CAC, as the former promotes generation of new CMs and the latter enhances their survival by new blood vessel formation [106]. Another example is given by Avolio and colleagues [111], who reported that using both human pericytes and CSC in the treatment of AMI was better than single cells in scar size reduction and in neovascularization. Nevertheless, mixed results were found when examining parameters of LV structure and function, as single cells were better in preventing LV end-diastolic volume (LVEDV) increase and in improving fractional shortening (FS). In spite of the generalized combination of CSC with other stem cells, there is also the option of combining stem cells from extra-cardiac sources altogether. For example, association of umbilical cord-derived MSCs and umbilical cord-derived endothelial cells was already tested in a rat model of AMI. Though, dual therapy did not show extra benefit over single therapies [48]. Recently, in an attempt to surmount the benefits of dual therapies, cardiac chimeras were developed, by fusion of CSC and BMMSC. In spite of the inherent disadvantages of genomic instability, cell senescence and the virus-mediated cell fusion, which hamper ready clinical translation, it was found that chimera therapy better improved cell engraftment, reduced scar size and increased angiogenesis. Besides, it surpassed single and dual cell therapies in terms of LV function amelioration [10]. Therefore, this finding encourages further investigation in the field of cell chimeras, mainly with regard to therapy safety, which is now the main concern before getting into pre-clinical trials. 
3.4.3. Sustained release of stem cells using scaffolds, matrices or microcarriers

The realization of the poor survival and retention of stem cells in the hostile myocardium has stimulated researchers to design strategies to protect them from the adversities found in an infarcted myocardium or in an already failing heart. Several hypotheses have been tested to shield cells from the hypoxic, serum-deprived, inflammatory, immuneactivated and pro-apoptotic infarcted/ischemic myocardium, namely the use of scaffolds, biomatrices, biomaterials, hydrogels (broadly accepted as synonyms) $[17,18,20,37,47,50,52,53,67,70,72,105,107,108$, 112-115] and microcarriers [36]. Numerous biomaterials have been used to overcome this hurdle, such as hyaluronan, collagen I, agarose, fibrin, fibrinogen and alginate/chitosan combinations. Globally, they are known to confer an extracellular matrix (ECM)-like environment, which favors acute retention of stem cells. Also, they promote migration of endothelial cells and smooth muscle cells and, simultaneously, confer CMs protection from apoptosis. In addition, these materials have low immunogenicity and have anti-inflammatory and pro-angiogenic properties $[17,18,20,37,50,53,67,107,108,112,115]$. This explains why delivery of stem cells in scaffolds has higher benefits to those delivered in aqueous or in culture media, with regard to cell retention and proliferation as well as structural and functional myocardial recovery. For instance, delivery of BMMNC in a hyaluronan hydrogel performed better than BMMNC alone in LV function recovery and in LV remodeling prevention in a rat model [18] and in a swine model of AMI [20]. Similarly, EPC delivered in a fibrin patch was found to be better than simple EPC injection in ameliorating LVEF, cardiac output, maximal developed pressure and contractility in a rat model of AMI. The use of EPC-fibrin patches brings the additional advantage of being already FDA-approved, which prompts their application into clinical trials [17]. However, fibrin is more viscous than fibrinogen and may, in fact, challenge cell injection and cell nutrition. That is why Rojas et al. [107] preferred to imprison iPSC in a fibrinogen matrix. Similarly, animals treated with iPSC and fibrinogen displayed improved LVEF in comparison to those treated with iPSC and medium.

In addition to the naturally occurring matrices, researchers have been manufacturing other more laborious scaffolds such as NapFF-NO hydrogel (naphthalene covalently conjugated to a short peptide, FFGGG, and $\beta$-galactose caged nitric oxide (NO) donor) [113], selfassembled biodegradable peptide amphiphile (incorporating cell adhesive ligand RGDS) nanomatrix [52] or plasma-functionalized electrospun poly- $\varepsilon$-caprolactone (PCL) fibers [114]. In NapFF-NO hydrogel, the sustained release of NO, through the activity of injected $\beta$ galactosidase, adds to the paracrine activity of the encapsulated ADMSC, enhancing angiogenesis. This strategy was mirrored in the recovery of LV structure and function of the mice after AMI induction [113]. Despite its potential, this technique brings another layer of complexity to the therapy by requiring co-administration of $\beta$-galactosidase. The use of self-assembling peptides (SAP) as reported by Ban et al. [52], beyond giving a support for stem cells, promotes their adhesion due to its RGDS domain and allows a sustained release due to the presence of a matrix metalloproteinase-2 degradable domain, that is gradually cleaved as a result of the inflammation inherent to an ischemic myocardium. With the use of SAP, it was possible to enhance ejection fraction and FS, as well as to reduce fibrosis in the used model of AMI. In the latter, PCL fibers were used because they are well tolerated by the immune system, highly available and already approved by FDA. It was found that the use of PCL to support stem cells conferred additional recovery of LVEF and FS [114].

Recently, it was reported an approach of sustained release of ADMSC and two growth factors, namely HGF and insulin-like growth factor-1 (IGF-1), by taking advantage of a poly(lactic-coglycolic acid) microcarrier (PAM) [36]. The developed PAM displays a biomimetic surface composed of fibronectin-like sequences that promote further ADMSC adhesion. It was found that PAM-mediated cell transport increased cell survival and viability and reduced their leakage. Moreover, the co-release of growth factors aided in the recovery of LV function by promoting cell proliferation and differentiation into the cardiac lineage and by stimulating angiogenesis. Nonetheless, care should be taken with the aforementioned approaches, as cell encapsulation/entrapment in matrices, spheres or microcarriers may hamper stem cell-host cell coupling and trigger arrhythmias [36].

There is a myriad of choices to provide a sustained release of stem cells, while giving them a support for retention in the myocardium. All of the studies depicted in Supplementary Table 1 that followed this strategy showed advantages of using biomatrices in, at least, one parameter. Hence, researchers should, whenever possible, test the differences of scaffolding their cells in biomatrices with independent experimental groups. However, the majority of the studies did not evaluate (or did not report) the arrhythmogenicity of the therapies and this is described as one of the main concerns in cell therapy [1] (Box 2, Fig. 2). Therefore, we strongly recommend to include this assessment in the evaluation of the cell therapy outcome in the forthcoming studies.

\subsubsection{Cell sheets and spheroids (tissue engineering)}

The major advantage of stem cell 3D culture, whether in a sheet or in a sphere fashion, is to preserve cell-cell and cell-matrix interactions, which prevents anoikis, increasing cell survival $[29,41,65,98]$. Also, when implanted as an organized tissue, stem cells are resistant to oxidative stress and inflammation, ubiquitous phenomena in the injured myocardium [98]. For example, Pätilä et al. [64] found that rats treated with skeletal myoblast sheets (SKS) had a lower CD11b ${ }^{+}$and CD68 ${ }^{+}$ leukocyte infiltration than those treated with SkMSC through intramyocardial injection (IMI). This corroborates a lower degree of immune system activation and a lower inflammatory status. Furthermore, this approach avoids the use of biomaterials (and, consequently, the need of extra control groups) and is characterized by the simplicity of application, preventing, for instance, injection-related complications such as cell clogging [41]. These tissue-engineering-based techniques have already been tested in several heart-related diseases, such as AMI [64,65,98], CMI [29], HF [116] and nonischemic dilated cardiomyopathy [41], with positive outcomes. For instance, in a swine model of CMI, the therapy with BMMSC sheets reduced LV end-systolic diameter (LVESD) and improved LVEF 8 weeks after sheet implantation [29]. In addition, in a mouse model of nonischemic dilated cardiomyopathy, it was found that epicardial delivery of ADMSC sheets reduced both LV end-diastolic diameter (LVEDD) and LVESD and ameliorated FS, 3 weeks after sheet delivery [41].

\subsubsection{Genetic engineering}

A large number of the studies depicted in Supplementary Table 1 resorted to some sort of genetic manipulation to increase the therapeutic potential of stem cells. The majority of the investigations sought to enhance the expression of a certain gene $[23,24,61,63,66,74,76,102$, $104,109,110,117]$ or to transfect cells with microRNAs (miRs) [16,19]. The only example of gene repression was reported by Wang et al. [39], who described the silencing of prolyl hydroxylase domain protein 2 gene (PHD2) as an alternative combined genetic and cell therapy approach. Broadly, the goal of stem cell transfection is to increase the chances of survival in the myocardium by increasing protection against hypoxia (e.g. HIF-1 overexpression [109] or stabilization by PHD2 silencing [39]); augmenting resistance to apoptosis (e.g. Bcl-xL [23], mir-133a mimic [16], mir-23a [19], thioredoxin-1 [110] overexpression or PHD2 silencing [39]); promoting stem cell-host cell coupling (e.g. connexin-43 overexpression [63]); stimulating angiogenesis (SVVYGLR peptide overexpression [66]) or simply by enhancing the positive paracrine growth factor-related stimulation (e.g. HGF [24], IGF-1 [61,117] or recombinant glucagon-like peptide-1 (GLP-1) overexpression [102, 104]). Regardless of the strategy, it was constantly observed a better outcome in genetically modified stem cells in comparison to naïve cells in, at least, one criterion. However, attention should be paid with these approaches, particularly if the cell transfection is mediated by viral agents (infection). In such cases, there is an increased 
Table 1

Common structural, functional and molecular follow-up parameters used in Clinical Trials.

\begin{tabular}{|c|c|c|c|c|}
\hline Clinical trial & Year & Structural and functional follow-up parameters & Molecular follow-up & Ref. \\
\hline REGENERATE-AMI & 2015 & $\begin{array}{l}\text { LVEF } \uparrow \\
\text { LV volumes } \leftrightarrow \\
\text { Infarcted LV mass / LV mass } \uparrow \text { (in cell group; better in placebo) }\end{array}$ & $\begin{array}{l}\text { NT-proBNP } \downarrow \\
\text { Troponin T, creatine kinase, C-reactive protein }{ }^{\mathrm{a}}\end{array}$ & {$[1,2]$} \\
\hline REGENERATE-DCM & 2015 & $\begin{array}{l}\text { LVEF } \uparrow \\
\text { LV volume } \leftrightarrow \\
\text { Myocardial mass } \leftrightarrow \\
\text { Exercise capacity } \uparrow\end{array}$ & $\begin{array}{l}\text { NT-proBNP } \downarrow \\
\text { Troponin T } \leftrightarrow \\
\text { Creatine kinase } \leftrightarrow\end{array}$ & [3] \\
\hline TICAP & 2015 & $\begin{array}{l}\operatorname{RVEF} \uparrow \\
\mathrm{RV} \text { volumes } \leftrightarrow \\
\text { pulmonary arterial pressure, pulmonary vascular resistance index } \leftrightarrow \\
\text { Cardiac index } \uparrow \\
\text { Ea/Ees } \downarrow\end{array}$ & $\begin{array}{l}\text { BNP } \downarrow \\
\text { Troponin I } \leftrightarrow \\
\text { Creatine kinase } \leftrightarrow\end{array}$ & {$[4,5]$} \\
\hline REVIVE & 2015 & $\begin{array}{l}\operatorname{LVEF} \uparrow \\
\operatorname{LVEDD} \leftrightarrow \\
\operatorname{LVESD} \downarrow \text { (in the non-ischemic HF group) }\end{array}$ & $\begin{array}{l}\text { BNP } \downarrow \text { (in the non-ischemic HF group) } \\
\text { Troponin I } \leftrightarrow \text { (except for } 2 \text { patients, in which it rose) } \\
\text { Creatine kinase }\end{array}$ & [6] \\
\hline $\mathrm{CD} 4^{+}$in ICM patients & 2014 & $\begin{array}{l}\text { LVEF } \uparrow \\
\text { LVEDD, LVEDV } \leftrightarrow \\
\text { LVESD, LVESV } \downarrow \\
\text { Exercise capacity } \uparrow\end{array}$ & NT-proBNP $\downarrow$ & [7] \\
\hline END-HF & 2014 & LVEF, LV volumes, LV infarct and peri-infarct volumes, SV, LV infarct volume $\leftrightarrow$ & creatine kinase-MB ${ }^{a}$ & [8] \\
\hline PRECISE & 2013 & $\begin{array}{l}\text { LVEF } \leftrightarrow \\
\text { Wall motion score index } \uparrow \\
\text { LV volumes } \leftrightarrow \\
\text { LV masses } \uparrow \\
\text { Myocardial perfusion } \uparrow \\
\text { Exercise tolerance } \uparrow\end{array}$ & $\mathrm{N} / \mathrm{A}$ & [9] \\
\hline autologous BMMNC in IHF patients & 2014 & $\begin{array}{l}\text { LVEF } \uparrow \\
\text { LV volumes } \downarrow \\
\text { Wall thickening } \uparrow \\
\text { (no inter-group difference in these } 3 \text { parameters) } \\
\text { Scar size } \downarrow \text { (only cell group) }\end{array}$ & NT-proBNP $\downarrow$ & [10] \\
\hline HEBE trial substudy & 2013 & $\begin{array}{l}\text { LVEF } \uparrow \\
\text { LV volumes } \downarrow \\
\text { Infarct mass } \downarrow\end{array}$ & $\mathrm{N} / \mathrm{A}$ & [11] \\
\hline
\end{tabular}




\section{REPAIR-AMI}

PROMETHEUS

Scar size and
Perfusion $\uparrow$

Wall thickness $\uparrow$

Contractility parameters $\uparrow$

autologous BMMSC in CAD + refractory angina patients

MAGIC cohort

RENEW [design]

C-CURE

CABG + autologous BMMNC in CMI patients

BMMNC in DCM pediatric patients

autologous $\mathrm{CD} 34^{+}$BMC in NIDCM patients
Exercise capacity

frequency of angina attacks $\downarrow$

LVEF (variable time-course behavior; at the end remained stable)

LVESV, LVEDV $\downarrow$ (at high-dosage)

Exercise capacity, frequency of angina episodes, assessment of clinical events

LVEF $\uparrow$

$\mathrm{LV}$ volumes $\leftrightarrow$

SV $\uparrow$ (at high-dosage)

Regional LV function (MRI assessment)

Scar mass $\downarrow$

LVEF $\uparrow$

V volumes $\downarrow$

Exercise capacity

LVEF $\uparrow$

VV volumes, LV mass $\leftrightarrow$

$\mathrm{SV}, \mathrm{CO} \uparrow$

Wall thickening $\uparrow$

$2012 \quad$ EF, FS $\uparrow$

VEDV, LVIDD

LVEF $\uparrow$

VEDD $\downarrow$ (a trend, n.s.)
$\mathrm{N} / \mathrm{A}^{\mathrm{b}}$

NT-proBNP $\downarrow$

Troponin $\mathrm{T} \leftrightarrow$ (except for 1 patient, in which it rose)

NT-proBNP $\downarrow$

NT-proBNP $\downarrow$

TNF- $\alpha$, IL-6

A

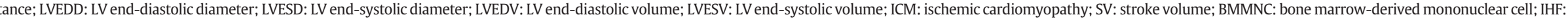

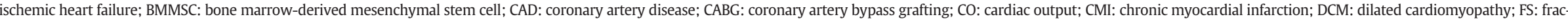
tional shortening; LVIDD: LV internal diameter at diastole; BMC: bone marrow cell; NIDCM: non-ischemic dilated cardiomyopathy; TNF- $\alpha$ : tumor necrosis factor- $\alpha$; IL-6: interleukin-6.

a Variation not reported.

b There is, though, an intention to set up a program of cardiac biomarker assessment.

c Assessed in an attempt to distinguish patients with good from those with poor myocardial cell homing; not used to monitor cell therapy efficacy. 
immunogenic and oncogenic risk, which makes virus-mediated genetically-engineered stem cells not consensual in the scientific and medical community $[19,23,39,61,66,74,102,104,110,117]$. This matter can be easily overcome by developing safer transfection methods such as electroporation [76] or through the use of non-viral plasmids [63, 109] or lipid-based transfection reagents [16]. Recently, Zhu et al. [24] developed an alternative transfection vehicle based on organicinorganic hybrid mesoporous organosilica nanoparticles, which offers several advantages over the common transfection vectors, namely higher biocompatibility and loading capacity, as well as easier internalization and lesser cytotoxicity. In this study, BMMNC were transfected with a HGF gene and the transformed cells were injected in rats subjected to AMI. 4 weeks after cell administration, these authors found that HGF-transfected BMMNCs reduced LV end-systolic volume (LVESV) and LVEDV and increased LVEF and FS over naïve BMMNC. Furthermore, post-mortem analysis showed that the levels of fibrosis were lower and the capillary and arteriolar density were higher in rats treated with transfected BMMNC. Hence, except for virus-mediated transfection approaches, genetic engineering of stem cells is a highly reasonable approach to strengthen the therapeutic potential of stem cells.

\subsubsection{Combined strategies}

As the reader can acknowledge so far, whenever the therapies with stem cells were employed with the use of biomatrices, tissue or genetic engineering techniques, it was observed better outcomes in a minimum of one evaluation criterion. That is the rationale behind the use of multiple strategies in stem cell therapy investigations [60,66,102,104]. For example, Uchinaka and colleagues [66] tested the therapeutic potential of osteopontin-derived SV peptide (SVVYGLR)-transfected SKS in a rat model of CMI. They observed that SV-transfected SKS surpassed wildtype SKS with regard to the preservation of LV structure and function. Moreover, 8 weeks after sheets transplantation, rats displayed decreased CM diameter and fibrosis, accompanied by increased capillary density. Despite the edema and accumulation of pleural fluid that might be caused by SV peptide, this approach has huge potential since SKS conserve ECM, avoiding cell detachment, while SV peptide has angiogenic activity, which increases the chances of myoblast survival and differentiation into CMs. Another combinatory approach can be achieved by the use of recombinant GLP-1 eluting CellBeads ${ }^{\mathrm{TM}}$. In this case, alginate-encapsulated MSCs are administered via intracoronary infusion (ICI) and their activity is improved by controlled release of a recombinant GLP-1 protein (with higher half-life), which is known to have both antiapoptotic and cardioprotective roles [102,104]. It is, therefore, strongly recommended to associate different approaches that will surely enhance the activity of stem cells, either paracrine or cardiomyogenic, in the process of post-injury myocardial healing. Although, for each strategy combined, one has to add additional control groups to the experimental design so that it is possible to address the extent of the benefits for each approach. This is a limitation of some studies depicted in Supplementary Table $1[36,53,75,101,102$, $104,110,114]$.

\subsection{Clinical translation}

A plethora of strategies have hitherto been trialed in numerous animal model studies in the field of regenerative medicine of the heart. Nevertheless, several hiccups in the design of the experiments delay the admission of such approaches into the pre-clinical and clinical stages of therapy experimentation (Box 5, Fig. 2). The first problem that can compromise a ready clinical translation is the choice of the animal model. Obviously, there is no debate regarding the use of rodents or pigs. The former should be used in proof-of-concept and mechanistic studies given its practical and economic advantages and the latter ought to be used when there is a potential stem cell therapy, optimized for rodent models, before testing in human trials [1]. Swine models, which are close, in structure and function, to the human's anatomy and physiology, provide a very good road towards clinical testing [44]. The research groups should, however, pay attention to the choice of the mice/rat models. There is the need of using a well-characterized animal model that gives enough confidence to expect changes in the structure and function of the myocardium whenever the disease is triggered. Also, as discussed earlier, immunodeficient animals should be avoided given that they do not represent a healthy immune system.

The second issue is related to the delivery approach. The majority of the studies is designed by the means of IMI (e.g. [21,57,58,61,111]) of cells but ICI (e.g. [15,30,34,76,102]), intravenous (IVI, [44,54]) and intramuscular injections [46] and epicardial delivery (e.g. [17,53,64-66]) are routes of choice, too. Stem cells can be administered directly by IMI or by epicardial delivery, although one should realize that these are very invasive procedures that can compromise the condition of the patients even further. In spite of the advantages conferred by cell sheets and grafts (Sections 3.4.3 and 3.4.4), these are commonly delivered onto the epicardium by thoracotomy, a very invasive, surgery-based procedure. In that sense, Martinez et al. [47] compared the administration of subamnion-cord-lining MSC spheroids grafts through lateral thoracotomy to in situ assembly via video-assisted thoracoscopic surgery (VATS) and found comparable improvements in both LV structure and function. Thus, in future studies, VATS may be of particular interest to use as a mean to administrate stem cells, while avoiding more invasive procedures. Although less invasive than IMI, ICI leads to early loss of stem cell due to the coronary blood flow [59]. Thus, as often as possible, these approaches should be replaced by less invasive delivery routes, namely IVI. Nonetheless, systemic administration via IVI is not ideal because there is always a high degree of cell distribution to outer tissues $[35,54]$. We consider more useful to maximize the delivery of stem cells to heart by, for instance, making use of bispecific antibodies in addition to IVI, such as the one reported by Yu et al. [118], than to resort to invasive approaches. The idea behind the use of bispecific antibodies is to direct stem cells injected intravenously directly to the myocardium due to the dual antibody-based recognition of stem cell's cluster of differentiation and of myosin light chains, exposed in injured cardiomyocytes. Hence, researchers should weight the risk/benefit of the two poles (invasiveness vs. efficacy) and make a final decision before proceeding into clinical trials (Box 5, Fig. 2).

Virus-mediated stem cell transfection is another drawback in the process of clinical translations. As discussed in Section 3.4.5. there is increased immunogenic, oncogenic and teratogenic risk when using transfected stem cells, therefore researchers should mind the use of virus-free alternative transfection methods namely electroporation and non-viral plasmids, in order to achieve a safer route to transform stem cells (Box 5, Fig. 2). This is a cutting-edge field and deserve more attention by the researchers.

The final, yet the most compromising, issue in clinical translation is related to the therapy monitoring, particularly the molecular analysis, which is performed post-mortem in animal models by, for instance, histological and immunohistochemical analysis as well as by PCR and western blot techniques making use of heart tissue samples [3,8,15,16, $21,22,29,34,38,41,51,54,61,62,64,105,109,110,119]$. Only Chen et al. [103]. Roy et al. [42] and Wiernicki et al. [62] have tried to quantify the levels of interleukin-10, TNF- $\alpha, \mathrm{C}$-reactive protein and the Nterminal of brain natriuretic peptide (BNP) pro-hormone (NT-proBNP) in the plasma from mice or from pigs. Even in clinical trials, structural and functional parameters, carried out by several imaging techniques, remain as conventional endpoints. A significant part of the clinical trials do not resort to any kind of molecular monitoring [81-84,88,89,92,94] and when they do, they are limited to some conventional cardiac markers (Table 1), mainly BNP [90,96], NT-proBNP [77-80,86,87,91, 93], in addition to creatine kinase [77,86,87,90,95-97], troponins I [90, $96,97]$ and $\mathrm{T}[77,80,86,87]$ and some inflammation markers, such as TNF- $\alpha$, IL-6 [79] and C-reactive protein [77,86]. Therefore, we suggest to screen biofluids (Box 5, Fig. 2) through omics approaches in the forthcoming preclinical studies. Molecular data retrieved from the 
exploratory characterization of easily collected biofluids, such as blood plasma and urine, could complement data from imaging techniques and would contribute to a higher degree of comprehension of the molecular basis of stem cell's mechanism of action, generally accepted to be played by paracrine cues. Furthermore, if certain molecular species, determined acutely after stem cell transplantation, were found to be correlated with long-term functional recovery of the animals, novel prognosis tools could be developed and potentially translated into the clinical setting. A rapid, yet predictive, molecular test performed with blood samples collected up until one week after transplantation (as later, stem cells would likely to be gone) would be valuable particularly when dealing with larger cohorts, whose functional evaluation through ultrasounds and electrocardiograms would become time-consuming and less practical. Ideally, this kind of tests would, in the future, notify the researchers/clinicians for the need of repeating stem cell administration, adjusting cell/matrix dosage or validate the use of a particular stem cell/strategy for a given patient (Box5 to Box3, Fig. 2) - approaching personalized and precision medicine.

\section{Summary and outlook}

Current available pharmacological therapies for heart diseases converging to HF only alleviate symptomatology and/or increase survival of patients without addressing the root of the problem, which is the lesion of the myocardium and consequent function decline. Actually, these drugs can even result in deleterious effects on overall patient health [4]. This observation together with the view of the heart as a self-renewing organ, prompted stem cell therapy to the spotlight in the last decades [1]. Notwithstanding, the lack of standardization in the design of basic research has been impairing the translation towards clinical trials. In this sense, following the analysis of the latest cell therapy studies on animal models as well as the contemporaneous clinical trials (Table 1) we sought to develop a flowchart with some suggestions to be implemented in the phase of study conceptualization using animal models, in order to accelerate translation to human studies.

Thus we strongly advice that future studies with animal models should start by choosing an immunocompetent murine model of myocardial infarction/heart failure. Once the animal model is well characterized and the expected deterioration of myocardium structure and function is achieved, then one can mind the time point of stem cell delivery. We acknowledge that the time of administration deserves optimization and, therefore, time points given in this paper are just referential. Also, stem cells should be preferentially retrieved from autologous sources in order to minimize their immunogenicity. After administration, if there is evidence of poor cell retention and survival, numerous strategies can be followed such as the combination of different stem cells, multiple administrations, cell delivery in biomaterial scaffolds, genetic and tissue engineering. Moreover, there is reason to believe that multiple approaches are more likely to achieve better cell engraftment. After optimization in murine models, the therapy can be scaled up to the swine model. In this phase, the delivery approach as well as the transfection methods (if needed) should be chosen, weighing their invasiveness and safety against the chances of stem cell retention. Moreover, before translation to clinical trials, alternative therapy monitoring tools to the common post-mortem analysis, such as antibody-based targeted proteomics (aiming to determining the levels of circulating paracrine cues) should be implemented and their correlation with long-term recovery should be assessed. This can be of special importance upon application in larger cohort studies, as an alternative to other time-consuming functional exams.

In short, there is a long way to go before stem cell therapy becomes a treatment option for patients afflicted with heart diseases. Nevertheless, standardization and optimization of animal models, as proposed in our flowchart, can accelerate the entry of such strategies in the clinical setting and provide novel therapeutic options for myocardial infarction and heart failure.

\section{Abbreviations}

Acta1 alpha-actin 1

ADMSC adipose tissue-derived mesenchymal stem cell

AFPC amniotic fluid-derived progenitor cell

AKT protein kinase $B$

AMI acute myocardial infarction

ANF atrial natriuretic factor

ANP atrial natriuretic peptide

Apaf-1 apoptotic protease activating factor-1

ATP adenosine triphosphate

AWA anterior wall amplitude

AWT anterior wall thickness

Bax Bcl-2-associated $X$ protein

Bcl-2 B-cell lymphoma 2

$\mathrm{Bcl}-\mathrm{xL} \quad$ B-cell lymphoma extra large

b-FGF basic fibroblast growth factor

$\mathrm{BiAb}$ bispecific antibody

BM bone marrow

BMMNC bone marrow-derived mononuclear cell

BMMSC bone marrow-derived stem cell

BMP-4 bone morphogenetic protein 4

BNP brain natriuretic peptide

BW body weight

CAC circulatory angiogenic cell

CBMSC cortical bone-derived mesenchymal stem cell

$\mathrm{CC} \quad$ cardiac chimera

CCL chemokine ( $\mathrm{C}-\mathrm{C}$ motif) ligand

$\mathrm{CD}$ cluster of differentiation

CFR coronary flow reserve

CL-MSC subamnion-cord-lining mesenchymal stem cell

$\mathrm{CM}$ cardiomyocyte

CMI chronic myocardial infarction

CMPC cardiomyocyte progenitor cell

CNT control

CO cardiac output

COL1a1 collagen alpha-1 (I) chain gene

COL3a1 collagen alpha-1 (III) chain gene

COX5A cytochrome $c$ oxidase, subunit 5A

COX5B cytochrome $c$ oxidase, subunit 5B

CPC cardiac progenitor cell

CPMSC chorionic plate-derived mesenchymal stem cell

CRYAB $\alpha$-crystallin B chain

CS cardiosphere

CSC cardiac stem cell

CTGF connective tissue growth factor

CTSD cathepsin D

CVMSC chorionic villi-derived mesenchymal stem cell

cx43 connexin 43

CXCL chemokine (C-X-C motif) ligand

CXCR4 C-X-C chemokine receptor type 4

DISA dual isotope simultaneous acquisition

DMOG dimethyloxalylglycine

$\mathrm{dP} / \mathrm{dt}$ developed pressure over time

EA electroacupuncture

EC endothelial cell

EDC explant-derived cell

EDE end-diastolic elastance

EDPVR end-diastolic pressure-volume relationship

EDV end-diastolic volume

EF ejection fraction

eNOS endothelial nitric oxide synthase

EPC endothelial progenitor cell

ESE end-systolic elastance

ESPVR end-systolic pressure-volume relationship

ESV end-systolic volume 
FAS fractional area shortening

fC-MSC fetal cardiac mesenchymal stem cell

FS fractional shortening

GATA4 NPPB gene transcriptional factor gene

GF growth factor

GFP green fluorescent protein

HA hyaluronan hydrogel

HCN4 hyperpolarization-activated cyclic nucleotide-gated cation channel 4

HGF hepatocyte growth factor

HIF-1 hypoxia-inducible factor 1

HMONs-PEI/pHGF hollow mesoporous organosilica nanoparticlespolyethyleneimine/HGF-encoding plasmid nanocomplexes

HO-1 heme oxygenase-1

HR heart rate

HRV heart rate variability

HUVEC human umbilical vein endothelial cell

HW heart weight

$\mathrm{I} / \mathrm{R} \quad$ ischemia/reperfusion

ICI intracoronary injection

IDH2 isocitrate dehydrogenase 2

IDH3A isocitrate dehydrogenase (NAD), subunit $\alpha$

IFN interferon

IGF-1 insulin-like growth factor 1

IHC immunohistochemistry

IL interleukin

IL-2R interleukin-2 receptor

IMI intramyocardial injection

ImI intramuscular injection

iMSC iPSC-derived mesenchymal stem cell

iPSC induced pluripotent stem cell

iPSC-VC iPSC-derived vascular cell

IVCT isovolumic contraction time

IVI intravenous injection

IVSDT intraventricular septum diastolic thickness

IVSST intraventricular septum systolic thickness

IVST interventricular septum thickness

JAM-A junctional adhesion molecule-A

$\mathrm{Kdr} \quad$ kinase insert domain receptor

LAD left anterior descending coronary artery

LV left ventricle

LVEDD left ventricle end-diastolic diameter

LVEDd left ventricle end-diastolic dimension

LVEDP left ventricle end-diastolic pressure

LVEDV left ventricle end-diastolic volume

LVEF left ventricle ejection fraction

LVESD left ventricle end-systolic diameter

LVESd left ventricle end-systolic dimension

LVESP left ventricle end-systolic pressure

LVESV left ventricle end-systolic volume

LVFAC left ventricle fractional area change

LVIDD left ventricle internal diameter at diastole

LVIdD left ventricle internal dimension at diastole

LVIDS left ventricle internal diameter at systole

LVIdS left ventricle internal dimension at systole

LVPWD left ventricle posterior wall diameter

LVR left ventricle remodeling

LVSP left ventricle systolic pressure

LVW left ventricle weight

$\mathrm{Ly}_{6 \mathrm{G}}{ }^{+} \quad$ lymphocyte antigen 6 complex

Mef2c myocyte enhancer factor 2c

MesP1 mesoderm posterior 1

MHC myosin heavy chain

MI myocardial infarction

miR microRNA

MLC myosin light chain
MMP matrix metalloprotease

MSC mesenchymal stem cell

Myh7 myosin heavy chain 7

N/A not assessed

NapFF-NO naphthalene covalently conjugated to a short peptide, FFGGG, and $\beta$-galactose caged nitric oxide donor

NDUFV NADH dehydrogenase flavoprotein

Nec-1 necrostatin-1

$\mathrm{NF}-\kappa \mathrm{B}$ nuclear factor $\kappa \mathrm{B}$

NHDF normal human dermal fibroblast

Nkx2.5 Nk2 homeobox 5

NOD non obese diabetic

NPPB natriuretic peptide B gene

NRG-1 neuroregulin-1

NT-proBNP N-terminal pro-brain natriuretic peptide

$\mathrm{PAB} \quad$ pulmonary artery banding

PAKT phosphorylated AKT

PAM poly(lactic-co-glycolic acid) microcarriers

PA-RGDS peptide amphiphile incorporating cell adhesive ligand Arg-Gly-Asp-Ser

PCDC primary cardiosphere-derived cell

PCL poly( $\varepsilon$-caprolactone)

$\mathrm{PCr}$ phosphocreatine

PDAC placenta-derived adherent cell

PDHA1 pyruvate dehydrogenase E1, subunit $\alpha$

PDMSC placenta-derived mesenchymal stem cell

PEC polyelectrolyte complex

PET positron emission tomography

PHD2 prolyl hydroxylase domain protein 2

PLB phospholamban

PLCA proximal left circumflex artery

PLX-PAD placental expanded cells

PRSW preload recruitable stroke work

PWT posterior wall thickness

RV right ventricle

RVEF right ventricle ejection fraction

SAP self-assembling peptide

SAX AC left ventricle area in the short axis

SCID severe combined immunodeficiency

SDF stromal-derived factor

SERCA2a ATPase, $\mathrm{Ca}^{2+}$ transporting, cardiac muscle, slow twitch 2

SkMSC skeletal muscle stem cell

SKS skeletal myoblast sheet

SMC smooth muscle cell

SPECT single positron emission computed tomography

SSEA-1 stage-specific embryonic antigen-1 (CD15)

SV stroke volume

SVP saphenous vein-derived pericyte

SW stroke work

TAC transverse aortic constriction

TGF- $\beta 1$ transforming growth factor $\beta 1$

TNF- $\alpha$ tumor necrosis factor $\alpha$

TnI troponin I

TnT troponin $\mathrm{T}$

Trx1 thioredoxin-1

Tx transplantation

UCB umbilical cord blood

UCBEC umbilical cord blood-derived endothelial cell

UCB-EPC umbilical cord blood-derived endothelial progenitor cell

UCB-MNC umbilical cord blood-derived mononuclear cell

UCMSC umbilical cord-derived mesenchymal stem cell

VATS video-assisted thoracoscopic surgery

VEGF vascular endothelial growth factor

VPC ventricular premature contraction

wk week

yr year 
Supplementary data to this article can be found online at http://dx. doi.org/10.1016/j.ijcard.2016.11.236.

\section{Conflict of interest}

The authors report no relationships that could be construed as a conflict of interest.

\section{Acknowledgments}

This work was supported by the Portuguese Foundation for Science and Technology (FCT) through UnIC, iBiMED, QOPNA research units (UID/IC/00051/2013, UID/BIM/04501/2013, PEst-C/QUI/UI0062/2013), by project DOCnet (NORTE-01-0145-FEDER-000003), supported by Norte Portugal Regional Operational Programme (NORTE 2020), under the PORTUGAL 2020 Partnership Agreement, through the European Regional Development Fund (ERDF) and also by the COST action BM1307- AFACTT. Rui Vitorino and Fábio Trindade are supported by individual fellowship grants (IF/00286/2015 and SFRH/BD/111633/2015, respectively).

Authors contribution: Fábio Trindade - literature search and mining; writing; Adelino Leite-Moreira, João Ferreira-Martins, Rita Ferreira, Inês Falcão-Pires, Rui Vitorino - writing and revision.

All authors have read and revised the manuscript and agree with its publication.

\section{References}

[1] V. Sousonis, K. Malliaras, J. Terrovitis, J. Nanas, in: D.V. Cokkinos (Ed.), Cell Therapy in Cardiac Diseases (Chapter 30), Introd. to Transl. Cardiovasc. Res, Springer 2015 pp. 565-582.

[2] E. Braunwald, Heart failure, JACC Hear. Fail. 1 (2013) 1-20.

[3] L. Hao, J. Hao, W. Fang, C. Han, K. Zhang, X. Wang, Dual isotope simultaneous imaging to evaluate the effects of intracoronary bone marrow-derived mesenchyma stem cells on perfusion and metabolism in canines with acute myocardial infarction, Biomed. Rep. 3 (2015) 447-452.

[4] J. Padda, G.L. Sequiera, N. Sareen, S. Dhingra, Stem cell therapy for cardiac regeneration: hits and misses, Can. J. Physiol. Pharmacol. 93 (2015) 835-841.

[5] K.A. Gerbin, C.E. Murry, The winding road to regenerating the human heart, Cardiovasc. Pathol. 24 (2015) 133-140.

[6] J.V. DiNella, J. Bowman, Heart transplantation, Crit. Care Nurs. Clin. North Am. 23 (2011) 471-479.

[7] R. Hullin, Heart transplantation: current practice and outlook to the future, Swiss Med. Wkly. 144 (2014) w13977.

[8] J.L. Carvalho, V.B. Braga, M.B. Melo, A.C.D. Campos, M.S. Oliveira, D.A. Gomes, A.J. Ferreira, R.A.S. Santos, A.M. Goes, Priming mesenchymal stem cells boosts stem cell therapy to treat myocardial infarction, J. Cell. Mol. Med. 17 (2013) 617-625.

[9] P. Menasché, Stem cells for the treatment of heart failure, Philos. Trans. R. Soc London B Biol. Sci. 370 (2015).

[10] P. Quijada, H.T. Salunga, N. Hariharan, J.D. Cubillo, F.G. El-Sayed, M. Moshref, K.M. Bala, J.M. Emathinger, A. De La Torre, L. Ormachea, R. Alvarez, N.A. Gude, M.A. Sussman, Cardiac stem cell hybrids enhance myocardial repair, Circ. Res. 117 (2015) 695-706.

[11] A. Finan, S. Richard, Stimulating endogenous cardiac regeneration, Front. Cell Dev. Biol. 3 (2015) 1-12.

[12] K.H. Wu, Y.L. Liu, B. Zhou, Z.C. Han, Cellular therapy and myocardial tissue engineering: the role of adult stem and progenitor cells, Eur. J. Cardio-Thoracic Surg. 30 (2006) 770-781.

[13] R. Ascione, J. Rowlinson, E. Avolio, R. Katare, M. Meloni, H. Spencer, G. Mangialardi, C. Norris, N. Krankel, G. Spinetti, C. Emanueli, P. Madeddu, Migration towards SDF1 selects angiogenin-expressing bone marrow monocytes endowed with cardiac reparative activity in patients with previous myocardial infarction, Stem Cell Res. Ther. 6 (2015) 53.

[14] A.R. Williams, K.E. Hatzistergos, B. Addicott, F. McCall, D. Carvalho, V. Suncion, A.R. Morales, J. Da Silva, M.A. Sussman, A.W. Heldman, J.M. Hare, Enhanced effect of combining human cardiac stem cells and bone marrow mesenchymal stem cells to reduce infarct size and restore cardiac function after myocardial infarction, Circulation 15 (2012) 213-223.

[15] S.T. Lehtonen, J. Mäkelä, S. Ohlmeier, K. Ylitalo, T. Juvonen, V. Anttila, P. Lehenkari, Analysis of molecular changes after autologous cell therapy in swine myocardial infarction tissue can reveal novel targets for future therapy, J. Tissue Eng. Regen. Med. 8 (2012) 97-105.

[16] D. Dakhlallah, J. Zhang, L. Yu, C.B. Marsh, M.G. Angelos, M. Khan, MicroRNA-133a engineered mesenchymal stem cells augment cardiac function and cell survival in the infarct heart, J. Cardiovasc. Pharmacol. 65 (2015) 241-251.

[17] P. Atluri, J.S. Miller, R.J. Emery, G. Hung, A. Trubelja, J.E. Cohen, K. Lloyd, J. Han, A.C. Gaffey, J.W. MacArthur, C.S. Chen, Y.J. Woo, Tissue-engineered, hydrogel-based endothelial progenitor cell therapy robustly revascularizes ischemic myocardium and preserves ventricular function, J. Thorac. Cardiovasc. Surg. 148 (2014) 1090-1098.

[18] C.-H. Chen, S.-S. Wang, E.I. Wei, T.-Y. Chu, P.C.H. Hsieh, Hyaluronan enhances bone marrow cell therapy for myocardial repair after infarction, Mol. Ther. 21 (2013) 670-679.

[19] J. Mao, Z. Lv, Y. Zhuang, MicroRNA-23a is involved in tumor necrosis factor- $\alpha$ induced apoptosis in mesenchymal stem cells and myocardial infarction, Exp. Mol. Pathol. 97 (2014) 23-30.

[20] C.-H. Chen, M.-Y. Chang, S.-S. Wang, P.C.H. Hsieh, Injection of autologous bone marrow cells in hyaluronan hydrogel improves cardiac performance after infarction in pigs, AJP Hear. Circ. Physiol. 306 (2014) H1078-H1086.

[21] J. Zhang, X.-H. Jia, Z.-W. Xu, F.-P. Ding, X. Zhou, H. Fu, Y. Liu, L.-L. Ou, Z.-J. Li, D.-L. Kong, Improved mesenchymal stem cell survival in ischemic heart through electroacupuncture, Chin. J. Integr. Med. 19 (2013) 573-581.

[22] C.-Q. Fan, S. Leu, J.-J. Sheu, Y.-Y. Zhen, T.-H. Tsai, Y.-L. Chen, S.-Y. Chung, H.-T. Chai, C.-K. Sun, J.-L. Yang, H.-W. Chang, S.-F. Ko, H.-K. Yip, Prompt bone marrow-derived mesenchymal stem cell therapy enables early porcine heart function recovery from acute myocardial infarction, Int. Heart J. 55 (2014) 362-371.

[23] X. Xue, Y. Liu, J. Zhang, T. Liu, Z. Yang, H. Wang, Bcl-xL genetic modification enhanced the therapeutic efficacy of mesenchymal stem cell transplantation in the treatment of heart infarction, Stem Cells Int. 2015 (2015) 1-14.

[24] K. Zhu, M. Wu, H. Lai, C. Guo, J. Li, Y. Wang, Y. Chen, C. Wang, J. Shi, Nanoparticleenhanced generation of gene-transfected mesenchymal stem cells for in vivo cardiac repair, Biomaterials 74 (2016) 188-199.

[25] S. Makino, K. Fukuda, S. Miyoshi, F. Konishi, H. Kodama, J. Pan, M. Sano, T. Takahashi, S. Hori, H. Abe, J. Hata, A. Umezawa, S. Ogawa, Cardiomyocytes can be generated from marrow stromal cells in vitro, J. Clin. Invest. 103 (1999) $697-705$.

[26] S.-W. Kim, M. Houge, M. Brown, M.E. Davis, Y.-S. Yoon, Cultured human bone marrow-derived $\mathrm{CD} 31(+)$ cells are effective for cardiac and vascular repair through enhanced angiogenic, adhesion, and anti-inflammatory effects, J. Am. Coll. Cardiol. 64 (2014) 1681-1694.

[27] J. Jaussaud, M. Biais, J. Calderon, J. Chevaleyre, P. Duchez, Z. Ivanovic, T. Couffinhal, L. Barandon, Hypoxia-preconditioned mesenchymal stromal cells improve cardiac function in a swine model of chronic myocardial ischaemia, Eur. J. Cardiothorac. Surg. 43 (2013) 1050-1057.

[28] A.R. Williams, V.Y. Suncion, F. McCall, D. Guerra, J. Mather, J.P. Zambrano, A.W. Heldman, J.M. Hare, Durable scar size reduction due to allogeneic mesenchymal stem cell therapy regulates whole-chamber remodeling, J. Am. Heart Assoc. 2 (2013) e000140.

[29] M. Kawamura, S. Miyagawa, S. Fukushima, A. Saito, K. Toda, T. Daimon, T. Shimizu, T. Okano, Y. Sawa, Xenotransplantation of bone marrow-derived human mesenchymal stem cell sheets attenuates left ventricular remodeling in a porcine ischemic cardiomyopathy model, Tissue Eng. Part A. 21 (2015) 1-19.

[30] T. Fatkhudinov, G. Bolshakova, I. Arutyunyan, A. Elchaninov, A. Makarov, E. Kananykhina, O. Khokhlova, A. Murashev, V. Glinkina, D. Goldshtein, Bone marrow-derived multipotent stromal cells promote myocardial fibrosis and reverse remodeling of the left ventricle, Stem Cells Int. (2015) 1-16 (2015).

[31] H. Zhu, Z.-K. Guo, X.-X. Jiang, H. Li, X.-Y. Wang, H.-Y. Yao, Y. Zhang, N. Mao, A protocol for isolation and culture of mesenchymal stem cells from mouse compact bone, Nat. Protoc. 5 (2010) 550-560.

32] J.M. Duran, C.A. Makarewich, T.E. Sharp, T. Starosta, F. Zhu, N.E. Hoffman, Y. Chiba, M. Madesh, R.M. Berretta, H. Kubo, S.R. Houser Bone-derived stem cells repair the heart after myocardial infarction through transdifferentiation and paracrine signaling mechanisms, Circ. Res. 113 (2013) 539-552.

33] J.D. Richardson, A.G. Bertaso, PJ. Psaltis, L. Frost, A. Carbone, S. Paton, A. Nelson, D.T.L. Wong, M.I. Worthley, S. Gronthos, A.C.W. Zannettino, S.G. Worthley, Impact of timing and dose of mesenchymal stromal cell therapy in a preclinical model of acute myocardial infarction, J. Card. Fail. 19 (2013) 342-353.

[34] M. Rigol, N. Solanes, S. Roura, M. Roqué, L. Novensà, A.P. Dantas, J. Martorell, M. Sitges, J. Ramírez, A. Bayés-Genís, M. Heras, Allogeneic adipose stem cell therapy in acute myocardial infarction, Eur. J. Clin. Investig. 44 (2014) 83-92.

35] E. Elhami, B. Dietz, B. Xiang J. Deng, F. Wang C. Chi, A.L Goertzen, S. Mzengeza, D. Freed, R.C. Arora, G. Tian, Assessment of three techniques for delivering stem cells to the heart using PET and MR imaging, EJNMMI Res. 3 (2013) 1-11.

[36] M. Savi, L. Bocchi, E. Fiumana, J.-P. Karam, C. Frati, F. Bonafé, S. Cavalli, P.G. Morselli, C. Guarnieri, C.M. Caldarera, C. Muscari, C.N. Montero-Menei, D. Stilli, F. Quaini, E. Musso, Enhanced engraftment and repairing ability of human adipose-derived stem cells, conveyed by pharmacologically active microcarriers continuously releasing HGF and IGF-1, in healing myocardial infarction in rats, J. Biomed. Mater. Res. Part A. 103 (2015) 3012-3025.

[37] M. Araña, J.J. Gavira, E. Peña, A. González, G. Abizanda, M. Cilla, M.M. Pérez, E. Albiasu, N. Aguado, M. Casado, B. López, S. González, M. Soriano, C. Moreno, J. Merino, J.M. García-Verdugo, J. Díez, M. Doblaré, B. Pelacho, F. Prosper, Epicardial delivery of collagen patches with adipose-derived stem cells in rat and minipig models of chronic myocardial infarction, Biomaterials 35 (2014) 143-151.

38] A. Paul, S. Srivastava, G. Chen, D. Shum-Tim, S. Prakash, Functional assessment of adipose stem cells for xenotransplantation using myocardial infarction immunocompetent models: comparison with bone marrow stem cells, Cell Biochem. Biophys. 67 (2013) 263-273.

[39] W.E. Wang, D. Yang, L. Li, W. Wang, Y. Peng C. Chen, P. Chen, X. Xia, H. Wang J. Jiang, Q. Liao, Y. Li, G. Xie, H. Huang, Y. Guo, L. Ye, D.D. Duan, X. Chen, S.R. Houser, C. Zeng, Prolyl hydroxylase domain protein 2 silencing enhances the survival and paracrine function of transplanted adipose-derived stem cells in infarcted myocardium, Circ. Res. 113 (2013) 288-300. 
[40] J. Liu, H. Wang, Y. Wang, Y. Yin, Z. Du, Z. Liu, J. Yang, S. Hu, C. Wang, Y. Chen, The stem cell adjuvant with Exendin-4 repairs the heart after myocardial infarction via STAT3 activation, J. Cell. Mol. Med. 18 (2014) 1381-1391.

[41] H. Hamdi, S.E. Boitard, V. Planat-Benard, J. Pouly, H. Neamatalla, P. Joanne, M.C. Perier, V. Bellamy, L. Casteilla, Z. Li, A.A. Hagège, M. Mericskay, P. Menasché, O. Agbulut, Efficacy of epicardially delivered adipose stroma cell sheets in dilated cardiomyopathy, Cardiovasc. Res. 99 (2013) 640-647.

[42] R. Roy, A. Brodarac, M. Kukucka, A. Kurtz, P.M. Becher, K. Jülke, Y.H. Choi, L. Pinzur, A. Chajut, C. Tschöpe, C. Stamm, Cardioprotection by placenta-derived stromal cells in a murine myocardial infarction model, J. Surg. Res. 185 (2013) 70-83.

[43] Y.-H. Liu, K.-Y. Peng, Y.-W. Chiu, Y.-L. Ho, Y.-H. Wang, C.-T. Shun, S.-Y. Huang, Y.-S. Lin, A.A. de Vries, D.A. Pijnappels, Human placenta-derived multipotent cells (hPDMCs) modulate cardiac injury: from bench to small \& large animal myocardial ischemia studies, Cell Transplant 24 (12) (2015) 2463-2478.

[44] H.-J. Chen, C.-H. Chen, M.-Y. Chang, D.-C. Tsai, E.Z. Baum, R. Hariri, U. Herzberg, P.C.H. Hsieh, Human placenta-derived adherent cells improve cardiac performance in mice with chronic heart failure, Stem Cells Transl. Med. 4 (2015) 269-275.

[45] J.A. Passipieri, T.H. Kasai-Brunswick, G. Suhett, A.B. Martins, G.V. Brasil, D.B. Campos, N.N. Rocha, I.P. Ramos, D.B. Mello, D.C. Rodrigues, B.B. Christie, B.J. SilvaMendes, A. Balduíno, R.M. Sá, L.M. Lopes, R.C. Goldenberg, A.C.C. de Carvalho, A.B. Carvalho, improvement of cardiac function by placenta-derived mesenchymal stem cells does not require permanent engraftment and is independent of the insulin signaling pathway, Stem Cell Res. Ther. 5 (2014) 1-14.

[46] S.-Y. Peng, C.-J. Chou, P.-J. Cheng, T.-Y. Tseng, W.T.-K. Cheng, S.W.S. Shaw, S.-C. Wu, Intramuscular transplantation of pig amniotic fluid derived progenitor cells has therapeutic potential in a mouse model of myocardial infarction, Cell Transplant. 24 (2014) 1003-1012.

[47] E.C. Martinez, D.-T. Vu, J. Wang, S. Lilyanna, L.H. Ling, S.U. Gan, A.L. Tan, T.T. Phan, C.N. Lee, T. Kofidis, Grafts enriched with subamnion-cord-lining mesenchymal stem cell angiogenic spheroids induce post-ischemic myocardial revascularization and preserve cardiac function in failing rat hearts, Stem Cells Dev. 22 (2013) 3087-3099.

[48] P.H. Suss, L.G.A. Capriglione, F. Barchiki, L. Miyague, D. Jackowski, L. Fracaro, A.V. Schittini, A.C. Senegaglia, C.L.K. Rebelatto, M. Olandoski, A. Correa, P.R.S. Brofman, Direct intracardiac injection of umbilical cord-derived stromal cells and umbilical cord blood-derived endothelial cells for the treatment of ischemic cardiomyopathy, Exp. Biol. Med. 240 (2015) 969-978.

[49] S.H. Lee, J.H. Lee, T. Asahara, Y.S. Kim, H.C. Jeong, Y. Ahn, J.S. Jung, S.-M. Kwon, Genistein promotes endothelial Colony-forming cell (ECFC) bioactivities and cardiac regeneration in myocardial infarction, PLoS One 9 (5) (2014) e96155.

[50] S. Roura, C. Soler-Botija, J.R. Bagó, A. Llucià-Valldeperas, M.A. Férnandez, C. GálvezMontón, C. Prat-Vidal, I. Perea-Gil, J. Blanco, A. Bayes-Genis, Postinfarction functional recovery driven by a three-dimensional engineered fibrin patch composed of human umbilical cord blood-derived mesenchymal stem cells, Stem Cells Transl. Med. (2015) 1-11.

[51] S. Oommen, S. Yamada, S. Cantero Peral, K.A. Campbell, E.S. Bruinsma, A. Terzic, T.J. Nelson, Human umbilical cord blood-derived mononuclear cells improve murine ventricular function upon intramyocardial delivery in right ventricular chronic pressure overload, Stem Cell Res. Ther. 6 (2015) 1-15.

[52] K. Ban, H.-J. Park, S.Y. Kim, A. Andukuri, K.-W. Cho, J.W. Hwang, H.J. Cha, W.-S. Kim, H.-W. Jun, Y.-S. Yoon, Cell therapy with embryonic stem cell-derived cardiomyocytes encapsulated in injectable nanomatrix gel enhances cell engraftment and promotes cardiac repair, ACS Nano 8 (2014) 10815-10825.

[53] V. Bellamy, V. Vanneaux, A. Bel, H. Nemetalla, S. Emmanuelle Boitard, Y. Farouz, P. Joanne, M.-C. Perier, E. Robidel, C. Mandet, A. Hagège, P. Bruneval, J. Larghero, O. Agbulut, P. Menasché, Long-term functional benefits of human embryonic stem cell-derived cardiac progenitors embedded into a fibrin scaffold, J. Hear. Lung Transplant. 34 (2014) 1198-1207.

[54] V.N.S. Garikipati, S. Jadhav, L. Pal, P. Prakash, M. Dikshit, S. Nityanand, Mesenchymal stem cells from fetal heart attenuate myocardial injury after infarction: an in vivo serial pinhole gated SPECT-CT study in rats, PLoS One 9 (2014) e100982.

[55] V. Lambert, E. Gouadon, A. Capderou, E. Le Bret, M. Ly, S. Dinanian, J.-F. Renaud, M. Pucéat, C. Rücker-Martin, Right ventricular failure secondary to chronic overload in congenital heart diseases: benefits of cell therapy using human embryonic stem cell-derived cardiac progenitors, J. Thorac. Cardiovasc. Surg. 149 (2015) 708-715.

[56] O. Bergmann, R.D. Bhardwaj, S. Bernard, S. Zdunek, F. Barnabé-Heider, S. Walsh, J. Zupicich, K. Alkass, B.A. Buchholz, H. Druid, S. Jovinge, J. Frisén, Evidence for cardiomyocyte renewal in humans, Science 324 (2009) 98-102 (80-. )

[57] F.G.P. Welt, R. Gallegos, J. Connell, J. Kajstura, D. D'Amario, R.Y. Kwong, O. CoelhoFilho, R. Shah, R. Mitchell, A. Leri, L. Foley, P. Anversa, M.A. Pfeffer, Effect of cardiac stem cells on left-ventricular remodeling in a canine model of chronic myocardial infarction, Circ. Heart Fail. 6 (2013) 99-106.

[58] D. Feyen, R. Gaetani, J. Liu, W. Noort, A. Martens, K. den Ouden, P.A. Doevendans, J.P.G. Sluijter, Increasing short-term cardiomyocyte progenitor cell (CMPC) survival by necrostatin-1 did not further preserve cardiac function, Cardiovasc. Res. 99 (2013) 83-91.

[59] K.U. Hong, Y. Guo, Q.-H. Li, P. Cao, T. Al-Maqtari, B.N. Vajravelu, J. Du, M.J. Book, X. Zhu, Y. Nong, A. Bhatnagar, R. Bolli, c-Kit + cardiac stem cells alleviate post-myocardial infarction left ventricular dysfunction despite poor engraftment and negligible retention in the recipient heart, PLoS One 9 (5) (2014) e96725.

[60] A.V. Boopathy, P.L. Che, I. Somasuntharam, V.F. Fiore, E.B. Cabigas, K. Ban, M.E. Brown, Y. Narui, T.H. Barker, Y.-S. Yoon, K. Salaita, A.J. García, M.E. Davis, The modulation of cardiac progenitor cell function by hydrogel-dependent Notch1 activation, Biomaterials 35 (2014) 8103-8112.

[61] R. Jackson, E.L. Tilokee, N. Latham, S. Mount, G. Rafatian, J. Strydhorst, B. Ye, M. Boodhwani, V. Chan, M. Ruel, T.D. Ruddy, E.J. Suuronen, D.J. Stewart, D.R. Davis,
Paracrine engineering of human cardiac stem cells with insulin-like growth factor 1 enhances myocardial repair, J. Am. Heart Assoc. 4 (2015) 1-12.

[62] B. Wiernicki, N. Rozwadowska, A. Malcher, T. Kolanowski, A. Zimna, A. Rugowska, M. Kurpisz, Human myoblast transplantation in mice infarcted heart alters the expression profile of cardiac genes associated with left ventricle remodeling, Int. J. Cardiol. 202 (2015) 710-721.

[63] T.J. Kolanowski, N. Rozwadowska, A. Malcher, E. Szymczyk, J.D. Kasprzak, T Mietkiewski, M. Kurpisz, In vitro and in vivo characteristics of connexin 43 modified human skeletal myoblasts as candidates for prospective stem cell therapy for the failing heart, Int. J. Cardiol. 173 (2014) 55-64.

[64] T. Pätilä, S. Miyagawa, Y. Imanishi, S. Fukushima, A. Siltanen, E. Mervaala, E. Kankuri, A. Harjula, Y. Sawa, Comparison of arrhythmogenicity and Proinflammatory activity induced by intramyocardial or epicardial myoblast sheet delivery in a rat model of ischemic heart failure, PLoS One 10 (4) (2015) e0123963.

[65] J. Homma, H. Sekine, K. Matsuura, M. Yamato, T. Shimizu, Myoblast cell sheet transplantation enhances the endogenous regenerative abilities of infant hearts in rats with myocardial infarction, J. Tissue Eng. Regen. Med (2015) 20151-20160.

[66] A. Uchinaka, N. Kawaguchi, Y. Hamada, S. Mori, S. Miyagawa, A. Saito, Y. Sawa, N. Matsuura, Transplantation of myoblast sheets that secrete the novel peptide SVVYGLR improves cardiac function in failing hearts, Cardiovasc. Res. 99 (2013) 102-110.

[67] L. Zhang, J. Guo, P. Zhang, Q. Xiong, S.C. Wu, L. Xia, S.S. Roy, J. Tolar, T.D. O'Connell, M. Kyba, K. Liao, J. Zhang, Derivation and high engraftment of patient-specific cardiomyocyte-sheet using induced pluripotent stem cells generated from adult cardiac fibroblast, Circ. Heart Fail. (2015) 156-166.

[68] S. Yamada, T.J. Nelson, G.C. Kane, A. Martinez-Fernandez, R.J. Crespo-Diaz, Y. Ikeda, C. Perez-Terzic, A. Terzic, Induced pluripotent stem cell intervention rescues ventricular wall motion disparity, achieving biological cardiac resynchronization post-infarction, J. Physiol. 591 (2013) 4335-4349.

[69] O. Iglesias-García, S. Baumgartner, L. Macrí-Pellizzeri, J.R. Rodriguez-Madoz, G. Abizanda, E. Guruceaga, E. Albiasu, D. Corbacho, C. Benavides-Vallve, M. Soriano-Navarro, S. González-Granero, J.J. Gavira, B. Krausgrill, M. RodriguezMañero, J.M. García-Verdugo, C. Ortiz-de-Solorzano, M. Halbach, J. Hescheler, B. Pelacho, F. Prósper, Neuregulin-1 induces mature ventricular cardiac differentiation from induced pluripotent stem cells contributing to cardiac tissue repair, Stem Cells Dev. 24 (2015) 484-496.

[70] Q. Xiong, L. Ye, P. Zhang, M. Lepley, J. Tian, J. Li, L. Zhang, C. Swingen, J.T. Vaughan, D.S. Kaufman, J. Zhang, Functional consequences of human induced pluripotent stem cell therapy: myocardial ATP turnover rate in the in vivo swine heart with postinfarction remodeling, Circulation 127 (2013) 997-1008.

[71] Q. Miao, W. Shim, N. Tee, S.Y. Lim, Y.Y. Chung, K.P.M.M. Ja, T.H. Ooi, G. Tan, G. Kong, H. Wei, C.H. Lim, Y.K. Sin, P. Wong, iPSC-derived human mesenchymal stem cells improve myocardial strain of infarcted myocardium, J. Cell. Mol. Med. 18 (2014) 1644-1654.

[72] M.-L. Liu, T. Nagai, M. Tokunaga, K. Iwanaga, K. Matsuura, T. Takahashi, M. Kanda, N. Kondo, A.T. Naito, I. Komuro, Y. Kobayashi, Anti-inflammatory peptides from cardiac progenitors ameliorate dysfunction after myocardial infarction, J. Am. Heart Assoc. 3 (2014) 1-25.

[73] S. Yamada, D.K. Arrell, A. Martinez-Fernandez, A. Behfar, G.C. Kane, C.M. PerezTerzic, R.J. Crespo-Diaz, R.J. McDonald, S.P. Wyles, J. Zlatkovic-Lindor, T.J. Nelson, A. Terzic, Regenerative therapy prevents heart failure progression in dyssynchronous nonischemic narrow QRS cardiomyopathy, J. Am. Heart Assoc. 4 (2015) 1-16.

[74] W. Lu, N. Yaoming, R. Boli, C. Jun, Z. Changhai, Z. Yang, S. Zhiyuan, mHCN4 genetically modified canine mesenchymal stem cells provide biological pacemaking function in complete dogs with atrioventricular block, Pacing Clin. Electrophysiol. 36 (2013) 1138-1149.

[75] T.I.G. van der Spoel, W.A. Gathier, S. Koudstaal, F. van Slochteren, S.J. of Lorkeers, J.P.G. Sluijter, I.E. Hoefer, P. Steendijk, M.J.M. Cramer, P.A. Doevendans, E. van Belle, S.A.J. Chamuleau, Autologous mesenchymal stem cells show more benefit on systolic function compared to bone marrow mononuclear cells in a porcine model of chronic myocardial infarction, J. Cardiovasc. Transl. Res. 8 (2015) 393-403.

[76] M.R. Ward, K.A. Connelly, R. Vijayaraghavan, A.K. Vaags, J.J. Graham, W. Foltz, M.R. Hough, D.J. Stewart, A. Dick, eNOS overexpressing bone marrow cells are safe and effective in a porcine model of myocardial regeneration following acute myocardial infarction, Cardiovasc. Ther. 31 (2013) e72-e78.

[77] S. Hamshere, T. Choudhury, D.A. Jones, D. Locca, P. Mills, M. Rothman, C. Knight, M Parmar, S. Agrawal, J. Martin, A. Mathur, A randomised double-blind control study of early intracoronary autologous bone marrow cell infusion in acute myocardial infarction (REGENERATE-AMI), BMJ Open 4 (2) (2014) e004258.

[78] I. Bergmane, A. Lacis, I. Lubaua, E. Jakobsons, A. Erglis, Follow-up of the patients after stem cell transplantation for pediatric dilated cardiomyopathy, Pediatr. Transplant. 17 (2013) 266-270.

[79] B. Vrtovec, G. Poglajen, L. Lezaic, M. Sever, D. Domanovic, P. Cernelc, A. Socan, S. Schrepfer, G. Torre-Amione, F. Haddad, J.C. Wu, Effects of intracoronary CD34+ stem cell transplantation in nonischemic dilated cardiomyopathy patients: 5year follow-up, Circ. Res. 112 (2013) 165-173.

[80] B. Assmus, W. DH, S. FH, E. Al, Effect of shock wave-facilitated intracoronary cell therapy on lvef in patients with chronic heart failure: the cellwave randomized clinical trial, JAMA 309 (2013) 1622-1631.

[81] J. Bartunek, A. Behfar, D. Dolatabadi, M. Vanderheyden, M. Ostojic, J. Dens, B. El Nakadi, M. Banovic, B. Beleslin, M. Vrolix, V. Legrand, C. Vrints, J.L Vanoverschelde, R. Crespo-Diaz, C. Homsy, M. Tendera, S. Waldman, W. Wijns, A. Terzic, Cardiopoietic stem cell therapy in heart failure: the C-CURE (Cardiopoietic 
stem Cell therapy in heart failURE) multicenter randomized trial with lineagespecified biologics, J. Am. Coll. Cardiol. 61 (2013) 2329-2338.

[82] J. Brickwedel, H. Gulbins, H. Reichenspurner, Long-term follow-up after autologous skeletal myoblast transplantation in ischaemic heart disease, Interact. Cardiovasc. Thorac. Surg. 18 (2014) 61-66.

[83] M. Lu, S. Liu, Z. Zheng, G. Yin, L. Song, H. Chen, X. Chen, Q. Chen, S. Jiang, L. Tian, Z. $\mathrm{He}, \mathrm{S}$. Hu, S. Zhao, A pilot trial of autologous bone marrow mononuclear cel transplantation through grafting artery: a sub-study focused on segmental left ventricular function recovery and scar reduction, Int. J. Cardiol. 168 (2016) 2221-2227.

[84] T.J. Povsic, C. Junge, A. Nada, R.A. Schatz, R.A. Harrington, C.J. Davidson, F.D. Fortuin, D.J. Kereiakes, F.O. Mendelsohn, W. Sherman, G.L. Schaer, C.J. White, D. Stewart, K Story, D.W. Losordo, T.D. Henry, A phase 3, randomized, double-blinded, active-controlled, unblinded standard of care study assessing the efficacy and safety of intramyocardial autologous CD34 + cell administration in patients with refractory angina: design of the RENEW study, Am. Heart J. 165 (2016) 854-861 (e2).

[85] B. Assmus, D.M. Leistner, V. Schächinger, S. Erbs, A. Elsässer, W. Haberbosch, R. Hambrecht, D. Sedding, J. Yu, R. Corti, D.G. Mathey, C. Barth, C. Mayer-Wehrstein, I. Burck, T. Sueselbeck, T. Dill, C.W. Hamm, T. Tonn, S. Dimmeler, A.M. Zeiher, Long-term clinical outcome after intracoronary application of bone marrowderived mononuclear cells for acute myocardial infarction: migratory capacity of administered cells determines event-free survival, Eur. Heart J. 35 (2014) $1275-1283$

[86] F. Choudry, S. Hamshere, N. Saunders, J. Veerapen, K. Bavnbek, C. Knight, D. Pellerin, D. Locca, M. Westwood, R. Rakhit, T. Crake, J. Kastrup, M. Parmar, S. Agrawal, D. Jones, J. Martin, A. Mathur, A randomized double-blind control study of early intra-coronary autologous bone marrow cell infusion in acute myocardial infarction: the REGENERATE-AMI clinical trial, Eur. Heart J. 37 (2016) 256-263.

[87] S. Hamshere, S. Arnous, T. Choudhury, F. Choudry, A. Mozid, C. Yeo, C. Barrett, N Saunders, A. Gulati, C. Knight, D. Locca, C. Davies, M.R. Cowie, S. Prasad, M. Parmar, S. Agrawal, D. Jones, J. Martin, W. McKenna, A. Mathur, Randomized trial of combination cytokine and adult autologous bone marrow progenitor cell administration in patients with non-ischaemic dilated cardiomyopathy: the REGENERATE-DCM clinical trial, Eur. Heart J. 36 (2015) 3061-3069.

[88] V. Karantalis, D.L. DiFede, G. Gerstenblith, S. Pham, J. Symes, J.P. Zambrano, J. Fishman, P. Pattany, I. McNiece, J. Conte, S. Schulman, K. Wu, A. Shah, E. Breton, J. Davis-Sproul, R. Schwarz, G. Feigenbaum, M. Mushtaq, V.Y. Suncion, A.C. Lardo, I. Borrello, A. Mendizabal, T.Z. Karas, J. Byrnes, M. Lowery, A.W. Heldman, J.M. Hare, Autologous mesenchymal stem cells produce concordant improvements in regional function, tissue perfusion, and fibrotic burden when administered to patients undergoing coronary artery bypass grafting: the prospective randomized study of mesenchymal stem Ce, Circ. Res. 114 (2014) 1302-1310.

[89] A.B. Mathiasen, M. Haack-Sørensen, E. Jørgensen, J. Kastrup, Autotransplantation of mesenchymal stromal cells from bone-marrow to heart in patients with severe stable coronary artery disease and refractory angina \&\#×2014; final 3-year follow-up, Int. J. Cardiol. 170 (2016) 246-251.

[90] A.N. Patel, S. Mittal, G. Turan, A.A. Winters, T.D. Henry, H. Ince, N. Trehan, REVIVE trial: retrograde delivery of autologous bone marrow in patients with heart failure, Stem Cells Transl. Med. 4 (2015) 1021-1027.

[91] T. Pätilä, M. Lehtinen, A. Vento, J. Schildt, J. Sinisalo, M. Laine, P. Hämmäinen, A. Nihtinen, R. Alitalo, P. Nikkinen, A. Ahonen, M. Holmström, K. Lauerma, R. Pöyhiä, M. Kupari, E. Kankuri, A. Harjula, Autologous bone marrow mononuclear cell transplantation in ischemic heart failure: a prospective, controlled, randomized, double-blind study of cell transplantation combined with coronary bypass, J. Hear. Lung Transplant 33 (2016) 567-574.

[92] E.C. Perin, R. Sanz-Ruiz, P.L. Sánchez, J. Lasso, R. Pérez-Cano, J.C. Alonso-Farto, E. Pérez-David, M.E. Fernández-Santos, P.W. Serruys, H.J. Duckers, J. Kastrup, S. Chamuleau, Y. Zheng, G.V. Silva, J.T. Willerson, F. Fernández-Avilés, Adiposederived regenerative cells in patients with ischemic cardiomyopathy: the PRECISE trial, Am. Heart J. 168 (2016) 88-95 (e2).

[93] G. Poglajen, M. Sever, M. Cukjati, P. Cernelc, I. Knezevic, G. Zemljic, F. Haddad, J.C. Wu, B. Vrtovec, Effects of Transendocardial CD34+ cell transplantation in patients with ischemic cardiomyopathy, Circ. Cardiovasc. Interv. 7 (2014) 552-559.

[94] L.F.H.J. Robbers, R. Nijveldt, A.M. Beek, A. Hirsch, A.M. van der Laan, R. Delewi, P.A. van der Vleuten, R.A. Tio, J.G.P. Tijssen, M.B.M. Hofman, J.J. Piek, F. Zijlstra, A.C. van Rossum, Cell therapy in Reperfused acute myocardial infarction does not improve the recovery of perfusion in the infarcted myocardium: a cardiac MR imaging study, Radiology 272 (2014) 113-122.

[95] T. Santoso, C.-W. Siu, C. Irawan, W.-S. Chan, I. Alwi, K.-H. Yiu, A. Aziz, Y.-L. Kwong H.-F. Tse, Endomyocardial implantation of autologous bone marrow mononuclear cells in advanced ischemic heart failure: a randomized placebo-controlled trial (END-HF), J. Cardiovasc. Transl. Res. 7 (2014) 545-552.

[96] S. Tarui, S. Ishigami, D. Ousaka, S. Kasahara, S. Ohtsuki, S. Sano, H. Oh, Transcoronary infusion of cardiac progenitor cells in hypoplastic left heart syndrome: three-year follow-up of the Transcoronary Infusion of Cardiac Progenitor Cells in Patients With Single-Ventricle Physiology (TICAP) trial, J. Thorac. Cardiovasc. Surg. 150 (2016) 1198-1208 (e2).

[97] S. Ishigami, S. Ohtsuki, S. Tarui, D. Ousaka, T. Eitoku, M. Kondo, M. Okuyama, J. Kobayashi, K. Baba, S. Arai, T. Kawabata, K. Yoshizumi, A. Tateishi, Y. Kuroko, T. Iwasaki, S. Sato, S. Kasahara, S. Sano, H. Oh, Intracoronary autologous cardiac progenitor cell transfer in patients with hypoplastic left heart syndrome: the TICAP prospective phase 1 controlled trial, Circ. Res. 116 (2015) 653-664

[98] H.-J. Lee, H.-J. Cho, Y.-W. Kwon, Y.-B. Park, H.-S. Kim, Phenotypic modulation of human cardiospheres between stemness and paracrine activity, and implications for combined transplantation in cardiovascular regeneration, Biomaterials 34 (2013) 9819-9829.

[99] X. Liu, J. Wang, X. Ji, S. Yu, L. Wei, Preconditioning of bone marrow mesenchymal stem cells by prolyl hydroxylase inhibition enhances cell survival and angiogenesis in vitro and after transplantation into the ischemic heart of rats, Stem Cell Res. Ther. 5 (2014) 1-12.

[100] F. Figeac, P.F. Lesault, O. Le Coz, T. Damy, R. Souktani, C. Trebeau, A. Schmitt, J. Ribot, R. Mounier, A. Guguin, C. Manier, M. Surenaud, L. Hittinger, J.L. Dubois-Rande, A.M. Rodriguez, Nanotubular crosstalk with distressed cardiomyocytes stimulates the paracrine repair function of mesenchymal stem cells, Stem Cells 32 (2014) 216-230.

[101] V. Karantalis, V.Y. Suncion-Loescher, L. Bagno, S. Golpanian, A. Wolf, C. Sanina, C. Premer, A.J. Kanelidis, F. McCall, B. Wang, W. Balkan, J. Rodriguez, M. Rosado, A. Morales, K. Hatzistergos, M. Natsumeda, I. Margitich, I.H. Schulman, S.A. Gomes, M. Mushtaq, D.L. DiFede, J.E. Fishman, P. Pattany, J.P. Zambrano, A.W. Heldman, J.M. Hare, Synergistic effects of combined cell therapy for chronic ischemic cardiomyopathy, J. Am. Coll. Cardiol. 66 (2015) 1990-1999.

[102] R. de Jong, G.P.J. van Hout, J.H. Houtgraaf, K. Kazemi, C. Wallrapp, A. Lewis, G. Pasterkamp, I.E. Hoefer, H.J. Duckers, Intracoronary infusion of encapsulated glucagon-like peptide-1-eluting mesenchymal stem cells preserves left ventricular function in a porcine model of acute myocardial infarction, Circ. Cardiovasc. Interv. 7 (2014) 673-683.

[103] Y. Chen, X. Teng, W. Chen, J. Yang, Z. Yang, Y. Yu, Z. Shen, Timing of transplantation of autologous bone marrow derived mesenchymal stem cells for treating myocardial infarction, Sci. China Life Sci. 57 (2014) 195-200.

[104] J.H. Houtgraaf, R. de Jong, K. Monkhorst, D. Tempel, E. van de Kamp, W.K. den Dekker, K. Kazemi, I. Hoefer, G. Pasterkamp, A.L. Lewis, P.W. Stratford, C. Wallrapp, F. Zijlstra, H.J. Duckers, Feasibility of intracoronary GLP-1 eluting CellBead ${ }^{\mathrm{TM}}$ infusion in acute myocardial infarction, Cell Transplant. 22 (2013) 535-543.

[105] R. Gaetani, D.A.M. Feyen, V. Verhage, R. Slaats, E. Messina, K.L. Christman, A. Giacomello, P.A.F.M. Doevendans, J.P.G. Sluijter, Epicardial application of cardiac progenitor cells in a 3D-printed gelatin/hyaluronic acid patch preserves cardiac function after myocardial infarction, Biomaterials 61 (2015) 339-348.

[106] N. Latham, B. Ye, R. Jackson, B.-K. Lam, D. Kuraitis, M. Ruel, E.J. Suuronen, D.J. Stewart, D.R. Davis, Human blood and cardiac stem cells synergize to enhance cardiac repair when cotransplanted into ischemic myocardium, Circulation 128 (2013) S105-S112.

[107] S.V. Rojas, A. Martens, R. Zweigerdt, H. Baraki, C. Rathert, N. Schecker, S. RojasHernandez, K. Schwanke, U. Martin, A. Haverich, I. Kutschka, Transplantation effectiveness of induced pluripotent stem cells is improved by a fibrinogen biomatrix in an experimental model of ischemic heart failure, Tissue Eng Part A. 21 (2015) 1991-2000.

[108] A.E. Mayfield, E.L. Tilokee, N. Latham, B. McNeill, B.K. Lam, M. Ruel, E.J. Suuronen, D.W. Courtman, D.J. Stewart, D.R. Davis, The effect of encapsulation of cardiac stem cells within matrix-enriched hydrogel capsules on cell survival, post-ischemic cell retention and cardiac function, Biomaterials 35 (2014) 133-142.

[109] S.-G. Ong, W.H. Lee, M. Huang, D. Dey, K. Kodo, V. Sanchez-Freire, J.D. Gold, J.C. Wu, Cross talk of combined gene and cell therapy in ischemic heart disease: role of exosomal microRNA transfer, Circulation 130 (2014) S60-S69.

[110] S.C. Suresh, V. Selvaraju, M. Thirunavukkarasu, J.W. Goldman, A. Husain, J. Alexander Palesty, J.A. Sanchez, D.W. McFadden, N. Maulik, Thioredoxin-1 (Trx1) engineered mesenchymal stem cell therapy increased pro-angiogenic factors, reduced fibrosis and improved heart function in the infarcted rat myocardium, Int. J. Cardiol. 201 (2015) 517-528.

[111] E. Avolio, M. Meloni, H.L. Spencer, F. Riu, R. Katare, G. Mangialardi, A. Oikawa, I. Rodriguez-Arabaolaza, Z. Dang, K. Mitchell, C. Reni, V.V. Alvino, J. Rowlinson, U. Livi, D. Cesselli, G. Angelini, C. Emanueli, A.P. Beltrami, P. Madeddu, Combined intramyocardial delivery of human pericytes and cardiac stem cells additively improves the healing of mouse infarcted hearts through stimulation of vascular and muscular repair, Circ. Res. 116 (2015) e81-e94.

[112] C. Ceccaldi, R. Bushkalova, C. Alfarano, O. Lairez, D. Calise, P. Bourin, C. Frugier, C. Rouzaud-Laborde, D. Cussac, A. Parini, B. Sallerin, S.G. Fullana, Evaluation of polyelectrolyte complex-based scaffolds for mesenchymal stem cell therapy in cardiac ischemia treatment, Acta Biomater. 10 (2014) 901-911.

[113] X. Yao, Y. Liu, J. Gao, L. Yang, D. Mao, C. Stefanitsch, Y. Li, J. Zhang, L. Ou, D. Kong, Q. Zhao, Z. Li, Nitric oxide releasing hydrogel enhances the therapeutic efficacy of mesenchymal stem cells for myocardial infarction, Biomaterials 60 (2015) $130-140$.

[114] A.G. Guex, A. Frobert, J. Valentin, G. Fortunato, D. Hegemann, S. Cook, T.P. Carrel, H.T. Tevaearai, M.N. Giraud, Plasma-functionalized electrospun matrix for biograft development and cardiac function stabilization, Acta Biomater. 10 (2014) 2996-3006.

[115] A. Ahmadi, B. McNeill, B. Vulesevic, M. Kordos, L. Mesana, S. Thorn, J.M. Renaud, E. Manthorp, D. Kuraitis, H. Toeg, T.G. Mesana, D.R. Davis, R.S. Beanlands, J.N. DaSilva, R.A. deKemp, M. Ruel, E.J. Suuronen, The role of integrin $\alpha 2$ in cell and matrix therapy that improves perfusion, viability and function of infarcted myocardium, Biomaterials 35 (2014) 4749-4758.

[116] J.J. Lancaster, E. Juneman, S.A. Arnce, N.M. Johnson, Y. Qin, R. Witte, H. Thai, R.S. Kellar, J. Ek Vitorin, J. Burt, M.A. Gaballa, J.J. Bahl, S. Goldman, An electrically coupled tissue-engineered cardiomyocyte scaffold improves cardiac function in rats with chronic heart failure, J. Heart Lung Transplant. 33 (2014) 438-445.

[117] L.L. Bagno, D. Carvalho, F. Mesquita, R.A. Louzada, B. Andrade, T.H. Kasai-Brunswick, V.M. Lago, G. Suhet, D. Ciptelli, J.P. Werneck-de-Castro, Sustained IGF-1 secretion 
by adipose-derived stem cell improves infarcted heart function, Cell Transplant 25 (9) (2015) 1609-1622

[118] J. Yu, Y.-K. Wu, Y. Gu, Q. Fang, R. Sievers, C.-H. Ding, J.E. Olgin, R.J. Lee, Immunomodification of enhancing stem cells targeting for myocardial repair, J. Cell. Mol. Med. 19 (2015) 1483-1491.
[119] D. Han, W. Huang, S. Ma, J. Chen, L. Gao, T. Liu, R. Zhang, X. Li, C. Li, M. Fan, Y. Chen, F. Cao, Ghrelin improves functional survival of engrafted adipose-derived mesenchymal stem cells in ischemic heart through PI3K/Akt signaling pathway, Biomed. Res. Int. (2015) 1-12. 